\title{
The formation of horse equipment of the early nomads of Central Asia
}

\section{Bokovenko Nicholay Anatoliyevich}

Candidate of Historical Sciences, Associate Professor, Employer of FSO Institute of history of material culture of the Russian Academy of Sciences. Russian Federation, 191186, Saint-Petersburg, Dvortsovaya Naberezhnaya, 18. E-mail: nibo25@yandex.ru.

Abstract. The frontier of 2 nd-1st millennium BC was an important milestone for formation of optimum system of economy - nomadic cattle breeding at which a flexible way of the seasonal pasture of the cattle with horizontal and vertical nomadism, generally horses and small cattle, allowed to graze it even in the winter. This convenient system of economy of many steppe people has existed practically without special changes up to now and was the progressive phenomenon. During this period change of material culture at cattle breeding cultures and emergence of numerous nomadic cultures of skif and saks type in Central Asia the early formation stages of which according to archaeological data are fixed in IX century BC, perhaps earlier.

The reasons of their emergence are caused by not only internal development, but also development of the horse under riding, creation of optimum types of bridle, etc., but, probably, certain climatic changes during this period, by moistening of the steppe that created an opportunity to move with livestock for long distances. Besides, in connection with significant progress in horse breeding and production from bronze more reliable bridles by large sets, in the company of early nomads (or the cultures of Scythian type) the rider (centaur) comes to the first place.

On material of the analysis of extensive archaeological cultures of early nomads, the author considers the process of formation of horse equipment in the territory of Central Asia.

Keywords: horse equipment; Saks era; Central Asia; riding cultures; domestication of horse.

\section{Орталық Азиядағы ерте көшпелілердің ат әбзелдерінің қалыптасуы}

\section{Боковенко Николай Анатольевич}

тарих ғылымдарының кандидаты, доцент, Ресей ғылым академиясының Материалдық мәдениет тарихы институты Федералдық мемлекеттік бюджеттік мекемесінің қызметкері. Ресей Федерациясы, Санкт-Петербург қ, 191186, Дворцовая набережная, 18. E-mail: nibo25@yandex.ru.

\begin{abstract}
Аңдатпа. Б.э. дейінгі 2-1 мыңжылдық көшпелі мал шаруашылығының елге оңтайлы жүйесін қалыптастыру үшін маңызды кезең болды - негізінен жылқы және ұсақ малы үшін тіпті қыста да шаруашылықтың икемді тәсілі маусымдық мал жайылымы көлденең және тік көшіп - қону үшін мүмкіндік берді. Бұл ыңғайлы шаруашылық жүйесі көптеген дала халықтарының тәжірибесінде іс жүзінде ерекше өзгерістерсіз осы күнге дейін жеткен прогрессивті құбылыс. Дәл осы кезеңде мал шаруашылығы мәдениетінде, материалдық мәдениетте орын алған өзгерістер тіркеледі және археологиялық деректер негізінде сонау б.э.д IX ғасырда тіркелген Орталық Азияда скиф-сақ үлгісіндегі көптеген көшпенді мәдениеттердің пайда болуы белең алады.

Олардың пайда болу себептері, негізінен тек қана ішкі дамуымен ғана байланыстырылмайды, сонымен қатар атты мініп жүруге ыңғайлап үйрету, оңтайлы үлгідегі жүгенді жасап шығару және т. б., шамасы осы кезеңде белгілі бір климаттық өзгерістер, дала ылғалдануы малмен үлкен қашықтыққа көшіп-қонуға мүмкіндік туғызып отырды.

Сонымен қатар, жылқы бағудағы елеулі өзгерістер прогресі, оның ішінде қоладан неғұрлым сенімді ауыздық - жүгендер топтамасын дайындаумен, қоғамда бірінші орынға көшпенділердің (немесе скиф типті мәдениетте) салт атты түрі (кентавр) шығады.

Автор ауқымды археологиялық мәдениеттер материалдарын талдау арқылы Орталық Азия аумағында жылқы әбзелдерінің қалыптасу процесін қарастырады.

Кілт сөздер: ат әбзелдері; сақ дәуірі; Орталық Азия; салт аттылар мәдениеті; жылқылар доместикациясы.
\end{abstract}

\section{Формирование конского снаряжения ранних кочевников Центральной Азии}

\section{Боковенко Николай Анатольевич}

кандидат исторических наук, доцент, сотрудник ФГБ учреждение науки Институт истории материальной культуры Российской академии наук. Российская Федерация, г.Санкт-Петербург, 191186, Дворцовая набережная, 18. E-mail: nibo25@yandex.ru.

Аннотация. Рубеж 2-1 тысячелетия до н.э. явился важной вехой для формирования оптимальной системы хозяйства - кочевого скотоводства, при котором гибкий способ сезонного выпаса скота с горизонтальным и вертикальным кочеванием, в основном коней и мелкого рогатого скота, позво- 
ляла пасти его даже зимой. Эта удобная система хозяйства у многих степных народов просуществовала практически без особых изменений до наших дней и была прогрессивным явлением. Именно в этот период фриксируется изменение материальной культуры у скотоводческих культур и появление многочисленных кочевых культур скифо-сакского типа в Центральной Азии, ранние этапы формирования которых наиболее четко по археологическим данным фиксируются уже в IX в. до н.э., возможно, и раньше.

Причины их возникновения, обусловлены не только внутренним развитием, освоением коня под верховую езду, созданием оптимальных типов узды и т.д., но, видимо, и определенными климатическими изменениями в этот период, увлажнением степи, что создавало возможность передвигаться со скотом на большие расстояния. Кроме того, в связи со значительным прогрессом в коневодстве и изготовлением из бронзы более надежных уздечных наборов большими сериями, на первое место в обществе ранних кочевников (или культурах скифского типа) выходит всадник (кентавр).

На материале анализа обширного материала археологических культур ранних кочевников автор рассматривает процесс формирования конского снаряжения на территории Центральной Азии. Ключевые слова: конское снаряжение; сакская эпоха; Центральная Азия; всаднические культуры; доместикация лошади.

әОЖ/ УДК 94(58)

\title{
Формирование конского снаряжения ранних кочевников Центральной Азии 1
}

\author{
Боковенко Н.A
}

Регион Центральной Азии, обладая уникальными фризико-географическими условиями (горные системы, степи, многочисленные водные ресурсы, разнообразные полезные ископаемые), сыграл важную роль в фоорировании культуры скотоводческих народов в древности.

Исследования палеоклимата этого региона, проведенные особенно в последнее время, свидетельствуют о значительных периодах усыхания и увлажнения аридной (степной) зоны Евразии, которые влияли на хозяйственную деятельность этих народов. Геохимические и полинологические исследования озерных отложений и разрезов Центральной Азии показывают значительные периодические изменения климата в различные периоды голоцена. Так, в эпоху бронзы (3-2 тысячелетие до н.э.) климат Центральной Азии был намного суше и холоднее по сравнению с современным. Значительное потепление и увлажнение степи (увеличение ее биомассы) началось в конце 2 тыс. до н.э. начале 1 тыс. до н.э. (Кулькова, Боковенко, ван Гил Б., Дергачев, Дирксен, Зайцева, Ван дер Плихт 2003). Умело адаптируясь к изменяющемуся климату, скотоводы развивали систему хозяйства, позволяющую им стабильно проживать длительное время. Важную роль в этом отношении играла доместикация животных и приспособление их к нуждам человека. На протяжении 3-2 тыс. до н.э. был длительный процесс поиска оптимальных форм узды и сбруи, которые позволили бы эффективно запрягать коня в колесный транспорт и управлять конем. В археологических памятниках обнаружены примитивные костяные эле менты конской узды, которые показывают на протяжении длительного времени тенденцию развития псалиев от круглых, прямоугольных к стержневым (Рисунок 1). Хотя кроме мягкой уздечки, видимо, существовало приспособление для управления конем в виде стягивающего ошейника. Скорее всего, к андронов-

1 Исследование проведено в рамках выполнения программы фундаментальных научных исследований государственных академий наук (или ФНИ ГАН) по теме государственной работы: №0184-2018-0009 «Взаимодействие древних культур Северной Евразии и цивилизаций Востока в эпоху палеометалла (IV тысячелетие до н.э. - І тысячелетие до н.э.)» 


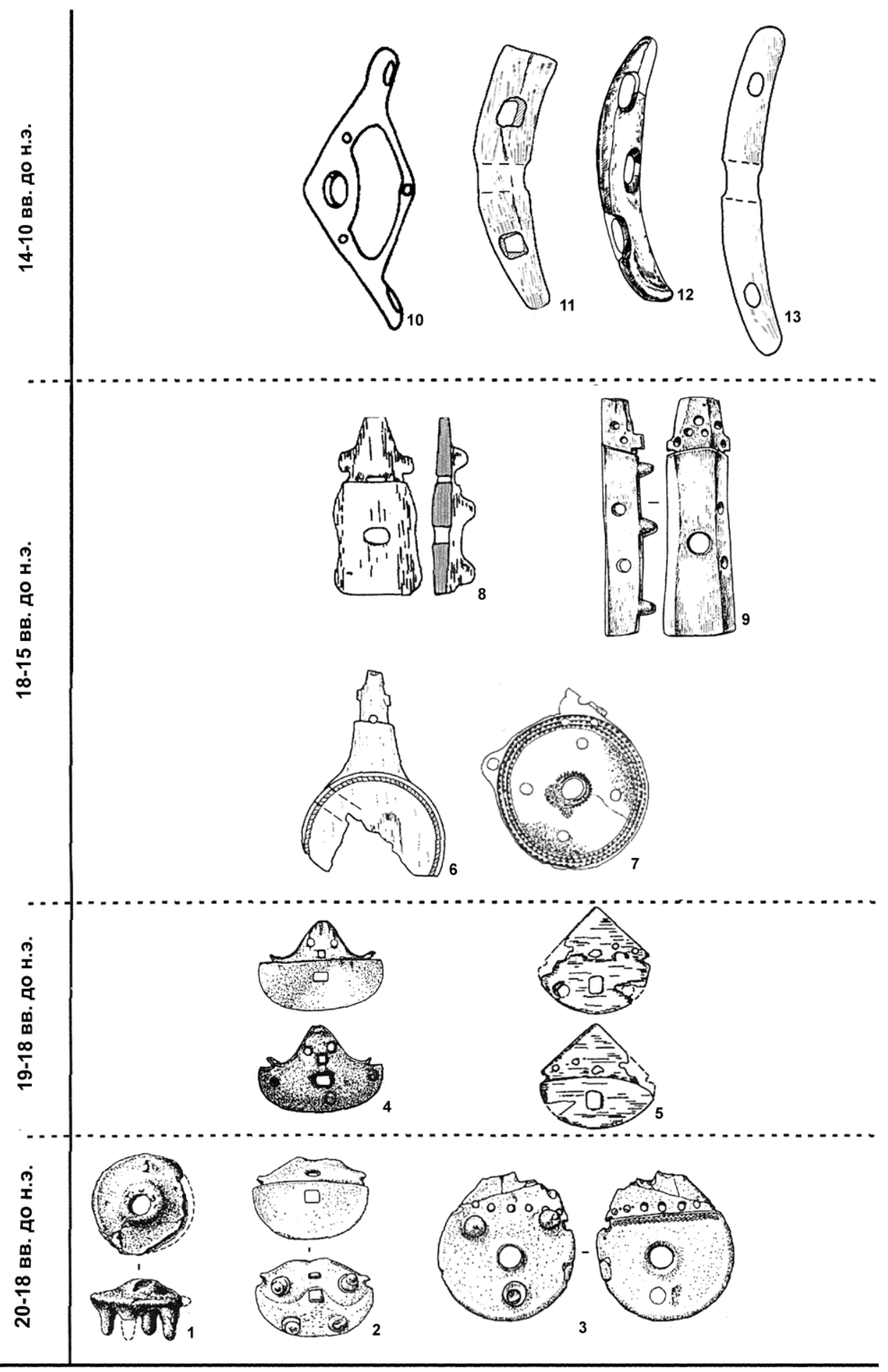

Рисунок 1. Схема развития псалиев эпохи бронзы в азиатских степях: 1 - Синташта, п.5 (по В.Ф. Генинг, Г.Б. Зданович, В.В. Зданович), 2-3 - Каменный Амбар-5 (по А.Н. Усачук), 4 - Кривое озеро (по И.В. Чечушков, А.В. Епимахов), 5 - Берлик II, к.10 (по Г.Б. Зданович), 7 - Илекшар-І (по А.Н. Усачук), 8 - Ак-сайман (по Г.Б. Зданович), 9 - Новые Ключи III ( по В.Н. Мышкину, М.А. Турецкому), 10 - Монголия (по В.В. Волков), 11 - Устинкино, сооружение 10, мог. 2 (по Д.Г. Савинову, В.В. Боброву), 12 - Торгажак (по Д.Г. Савинову), 13 - Каменный Лог I (по М.Н. Комаровой) 
скому периоду относится уникальное изображение коня сейминско-турбинского типа с ошейником, перекрывающее часть окуневской личины из Лебяжьего на Среднем Енисее. Оно несомненно демонстрирует один из этапов приручения коня с помощью этого приспособления.

Маловероятно, что это была всадническая культура, так как кроме псалиев упряжной сбруи ни захоронений, ни изображений всадников для этого времени пока не обнаружено. Зато известно большое количество петроглифов с изображением колесниц от Скандинавии до Индии и от Италии до Монголии, но наибольшее их разнообразие концентрируется в Центральной Азии (от Казахстана до Монголии). Престижные захоронения колесничих (XVII-XV вв. до н.э.) распространяются из Приуралья (Синташта) в Казахстан (андроновские памятники петровского типа) и вплоть до Китая (че-ма кены периодов Инь и Западного Чжоу).

Рубеж 2-1 тысячелетия до н.э. явился важной вехой для формирования оптимальной системы хозяйства - кочевого скотоводства, при котором гибкий способ сезонного выпаса скота с горизонтальным и вертикальным кочеванием, в основном коней и мелкого рогатого скота, позволяла пасти его даже зимой. Именно в малоснежных степях Центральной Азии эта система была оптимальной, снежные степи Восточной Европы требовали стойлового содержания скота зимой (Руденко 1961). Эта удобная система хозяйства у многих степных народов просуществовала практически без особых изменений до наших дней и была прогрессивным явлением. Именно в этот период фриксируется изменение материальной культуры у скотоводческих культур и появление многочисленных кочевых культур скифро-сакского типа в Центральной Азии, ранние этапы формирования которых наиболее четко по археологическим данным фиксируются уже в IX в. до н.э., возможно, и раньше (Грязнов 1983).

Причины их возникновения обусловлены не только внутренним развитием, освоением коня под верховую езду, созданием оптимальных типов узды и т.д., но, видимо, и определенными климатическими изменениями в этот период, увлажнением степи, что создавало возможность передвигаться со скотом на большие расстояния.

В связи со значительным прогрессом в коневодстве и изготовлением из бронзы более надежных уздечных наборов большими сериями, на первое место в обществе ранних кочевников (или культурах скифского типа) выходит всадник (кентавр). Эти элементы достаточно быстро распространились в восточных степных культурах, поскольку генетически связаны с предшествующими подвижными культурами эпохи бронзы, где существовали уже колесницы и первичные навыки управления конем. Именно в этом регионе фиксируется раз-ведение различных пород лошадей (в том числе, и высокоаллюрных) (Витт 1952).

При синхронизации существующих периодизаций археологических культур ранних кочевников удается выделить три условных этапа развития конского снаряжения сакской эпохи: 1 этап - начальный (раннесакский - аржанский майэмирский - киммерийский) - X-VII вB. до н.э.; 2 этап - классический (сакский - алды-бельский - раннескифский) - VII-VI вв. до н.э.; 3 этап - поздний (берельско-пазырыкский - саглынский - позднесакский) - V-III вв. до н.э.

Типологическая классификация конского снаряжения. Конское снаряжение слагается из двух основных компонентов: узды и сбруи. Узда - часть сбруи, надеваемая на голову коня и состоящая из удил, псалиев и системы ремней (нащечный, наносный, подгубный, налобный, подскульный, затылочный, лыска, соединяющий наносный и налобный), повод с чумбуром. К узде также относятся различные соединительные обоймы и украшения (развилки, перекрестники ремней, нащечные бляхи, затылочные - ворворки, застежки, блок чумбура, налобные и другие украшения ремней). Сбруя (верховая), кроме уздечки, содержит потник, чепрак, подпругу, седло, стремена, нагрудный ремень и нахвостники. 
Многие из этих современных элементов выработались в раннесакское время, седло же только начало формироваться, а стремена появились только в раннем средневековье.

Общей типологии элементов узды долгое времени не было. В ряде археологических работ затрагивались лишь отдельные аспекты хронологии, классифрикации некоторых элементов узды и сбруи (Tallgren 1917; Грязнов 1951; Киселев 1951; Руденко 1953; 1960; Гришин 1960; Кадырбаев 1966, С.383-388; 1968, С.21-36; Членова 1967; Акишев 1973, С.51-55; Акишевы, 1978, С.38-44; Кадырбаев 1980, С.49-51; Грязнов 1980; 1983; Марсадолов 1985). Но более систематизированный типологический подход осуществлен после открытия кургана Аржан 1-1 (Боковенко 1979; 1981; 1986). Позднее, к этой теме обращались алтайские археологи, вводя в научный оборот новый важный материал (Кирюшин, Тишкин 1997; Шульга 2008). Ими предложены свои классификации конского снаряжения, но принципиально они не изменили уже существующие ранее.

В данной статье приводятся некоторые разработки моей диссертации 1986 года, в которых учтены и последние материалы.

Наиболее древняя часть сбруи, первоначально, видимо, была значительно проще и состояла из одних ремней, затем появились костяные псалии, бронзовые удила и ряд других элементов, что в сакское время привело к значительному усложнению снаряжения верхового коня.

Выбор признаков. Понимание вышеуказанных моментов позволяет уже предварительно наметить линию развития конской сбруи - как функциональной единицы, состоящей, в свою очередь, из взаимозависящих компонентов. Наиболее функционально значимые в сбруе - удила и псалии, а также система ремней между ними и всадником. В свою очередь, эти составные компоненты вступают между собой в фрункциональные связи с четкой иерархией. Наличие определенной фрормы удил, особенно окончаний (т.е. места крепления с псалиями), как фрункционально исходное, требует определенного вида формы псалиев, расположения отверстий и т.д. Внутри функционально обусловленных пределов изменчивости возможен выбор вариантов (величина внешних окончаний, форма и количество отверстий и т.д.). Это разнообразие форм скорее всего определяется пространственно-временной обусловленностью удил, псалиев, их определенной культурной принадлежностью в древности (Рисунок 1). Такие варианты форм и приняты за признаки вещей. Неправильный подход к материалу, отражающий недостаточно обоснованный выбор признаков (оснований, параметров и т.п.), может привести к созданию классификаций, искажающих реальную ситуацию культурных членений.

Эти моменты таковы:

1. Экстерьер лошади (наружные формы ее тела) чрезвычайно различен и зависит не только от природных условий существования, но и от функций, которые выполняет лошадь. В древности подобная зависимость экстерьера от назначения лошади также имела место, но, видимо, не в такой степени, как сейчас. Во всяком случае, по археологическому материалу азиатских степей скифского времени V-III вв. до н.э. достаточно определенно - по костным остаткам и при сопоставлении с дошедшими до нас изображениями - выделяются несколько типов лошадей: верховые и упряжные кони, которые в свою очередь делятся на «простых», коней «знати», «царя» (Витт 1952, С.208). Различный экстерьер и назначение лошадей, видимо, требовали соответствующего снаряжения, определенной системы взнуздывания и упряжи. Для выявления возможных дискретных групп ширины морды лошадей замерялась рабочая часть удил (длинна стержней удил между окончаниями). Результаты измерений (Рисунок 2) не позволяют выявить три дискретные группы по ширине рабочей части удил. 


\begin{tabular}{|c|c|c|c|c|c|c|c|c|c|c|c|c|}
\hline 9 & & & & $\mathrm{O}^{2}$ & 0 & $\Longrightarrow$ & & & & & & \\
\hline 8 & & & & 80 & $(00)$ & $\sqrt{20}$ & & (Q) & (D)= & & प0, & \\
\hline 7 & & (O) & & & 0 & D & $D=$ & Q & Dr & Dr & 四 & Dr \\
\hline 6 & & (3) & & (ब) & (6) & Bo & $\sqrt{10}=$ & Q0: & (B) $=$ & & 00 & $\sqrt{102}$ \\
\hline 5 & & (C) & (b) & & $\mathrm{O}^{2}$ & Bo & & & Do $=$ & & & \\
\hline 4 & & @o & (ृ) & $\beta_{0}=$ & (100- & Do- & & (1) & & & & \\
\hline 3 & o- & (o) & & & & Do & & & Do: & Do & - & 0 \\
\hline 2 & 00 & & & & & & & & & & & \\
\hline 1 & Q & $\Longrightarrow$ & & & & @ & $\Rightarrow$ & & & & & \\
\hline подтипи & $A$ & 5 & $B$ & $\Gamma$ & Д & $E$ & ж & 3 & и & $\mathrm{K}$ & $\pi$ & $M$ \\
\hline \begin{tabular}{|l} 
типь \\
\end{tabular} & & & I & & & & II & & II & & & $\mathbf{V}$ \\
\hline
\end{tabular}

Рисунок 2. Схема типологического развития окончаний бронзовых удил Саяно-Алтая. По вертикали - вариации форм окончаний удил, по горизонтали - этапы развития

2. Конструкция конского снаряжения для раннескифского в основном представлена уздечкой, главными, наиболее фрунционально значимыми элементами которой являются удила и псалии. Удила, вложенные в рот коня, при управлении им должны оказывать давление на углы рта, язык и десна нижней челюсти в беззубой части. В зависимости от силы давления (от слабого, мягкого, до сильнейшего, травмирующего ротовую полость), которое оказывают удила при управлении конем, их подразделяют на несколько видов: простые, мягкие и строгие. Мягкость и строгость удил обусловлена их конструкцией и формой звеньев (грызла). Например, широкие гладкие грызла не беспокоят лошадь и способствуют мягкому управлению. Наоборот, тонкие, с неровной шершавой поверхностью грызла раздражают рот лошади, заставляют ее повиноваться всаднику. В тех случаях, когда болезненность от удил ощущается только на одной стороне рта, лошадь поворачивает голову в сторону боли, чем ослабляет давление удил с этой стороны. Знание этой особенности побуждает в отдельных случаях применять двухгрызловые удила, у которых одно грызло оказывает мягкое действие, другое - более жесткое, строгое действие (Урусов 1911, С.369; Карлсен 1978, С.180). В техническом отношении такие грызла исполнены также по-разному: более строгая часть либо витая, либо имеет бугорки, выступы и т.д.

3. Процесс приручения коня, видимо, занял длительный период времени и проходил на различных территориях по-разному. Техническая оснащенность конское снаряжение также весьма варьирует. Этот процесс наибольшего размаха 
достиг где-то в начале 1 тыс. до н.э., когда в связи с массовым внедрением бронзы в эту категорию культуры, появилась реальная возможность коренным образом совершенствовать как сбрую, так и способы управления конем.

Перечисленные выше моменты заставляют при создании классифиикации учитывать в первую очередь такие особенности, которые характеризуют удила и псалии как функциональные единицы. Это прежде всего конструкция удил (одночастность, двучастность, трехчастность), внешнее оформление грызл, их окончание (однокольчатые, двукольчатые, стремечковидные и т.д.).

Классификация удил. С учетом всех вышеизложенных особенностей для учтенных более 500 экземпляров удил выделено 16 признаков:

А. Два отверстия на конце звена удил: 1 - внешнее кольцо больше внутреннего; 2 - равновеликие кольца в одной плоскости; 3 - равновеликие кольца в перпендикулярных плоскостях; 4 - внутреннее больше внешнего (внутреннее - кольцо); 5 - внутреннее меньше и выделяется из общей конфигурации окончания звена; 6 - внутреннее меньшее отверстие вписано в конфигурацию окончания звена; 7 - отсутствие дополнительных отверстий.

Б. Внешнее оформление концов звеньев удил: 8 - кольцевидное; 9 - овальное; 10 - усеченно-полукруглое; 11 - сегментарное; 12 - треугольное; 13 - трапециевидное; 14 - прямоугольное; 15 - стремечковидное.

В. Дополнительные элементы: 16 - выступы по краям фигур вдоль общей оси звена.

Такие признаки, как ладьевидное окончание звена, равновеликие смыкающиеся между собой кольца, либо окончания удил в виде шляпки без всяких отверстий являются единичными или, в некоторых случаях, возникают в результате случайной деформации, поэтому из классификаций они исключены, но все же учтены в исследовании. В некоторых случаях они даже в единичном экземпляре могут представлять отдельный тип, как например, удила из Минусинской котловины (хранятся в археологическом музее ТГУ) (Членова 1967, табл. 16-22А).

Формы бронзовых удил на основе 16 выделенных признаков и благодаря тому, что в 42 случаях бронзовые удила состоят из звеньев удил с различным окончанием. В совокупности все удила по окончаниям формируются в 12 устойчивых типологически развивающихся групп (Рисунок 2):

А - удила, имеющие на конце звена равновеликие круглые отверстия в одной плоскости (A2), либо в перпендикулярных (А3). Отверстия небольшие, в диаметре не превышающие 12 мм.

Б - удила, имеющие на конце звена также 2 отверстия, но внешнее кольцо больше внутреннего (БЗ-Б6).

В - удила с двумя отверстиями на конце звена, внешнее большее выполнено в фрорме овала (В4-В5).

Г - удила с двумя отверстиями на конце звена, внешнее большее выполнено в виде полукруга (Г4-Г6). Причём, на позднем этапе внутреннее отверстие становится больше внешнего (Г8).

Д - удила с двумя отверстиями на конце звена, внешнее выполнено в виде сегмента (Д4-Д7), позднее внутреннее круглое отверстие исчезает (Д7), а затем появляется увеличенное в размерах (Д8). Всего 40 экз.

E - удила с двумя отверстиями на конце звена, внешнее подтреугольной формы (E3-E6). Здесь аналогичная ситуация развития удил в группе Д. Форма удил Е7 сменяется E8.

ж - удила той же формы, что и Е, но имеют дополнительные выступы вдоль общей оси звена (Ж6, Ж7). 
3 - удила с двумя отверстиями на конце звена, внешнее большее трапециевидной формы $(34,36)$. Развитие аналогично группе Д, Е. Форма удил 37 сменяется 38.

И - удила с двумя отверстиями на конце звена, внешнее большее выполнено в виде стремечка (ИЗ, И5, И6). Ситуация такая же, как в группах Д, Е, 3. Форма И7 сменяется формой И8.

К - удила той же формы, что и в группе И, но имеют дополнительные выступы вдоль общей оси звена (КЗ, К7).

$Л$ - удила с двумя отверстиями на конце звена, внешнее подпрямоугольной формы (Л3, Л6). Здесь ситуация, аналогичная развитию удил группы Д, Е, 3, И. Форма удил $Л 7$ сменяется формой Л8.

М - удила той же фрормы, что и Л, но имеют дополнительные выступы общей оси звена (M3, M6, M7).

Каждая из этих групп проходит через определенные этапы типологического развития, которые в общих чертах можно представить в следующем виде:

I этап. Существование однокольчатых и двукольчатых удил с небольшим отверстием (10-12 мм), копирующих «ременные» удила.

I/ этап. Появление на удилах дополнительных отверстий различных форм (сегментированные, треугольные, стремечковидные и т.д.). Вписывание внутреннего маленького отверстия в общую фрорму окончания звена.

III этап. Исчезновение дополнительного маленького отверстия.

IV этап. Появление внутреннего большого отверстия.

$V$ этап. Исчезновение внешних отверстий, видимо, как нецелесообразных.

На наш взгляд, выявилась целостная структура развития форм удил (группы A-M), причем формы взаимосвязаны как по горизонтали, так и по вертикали. Из этой схемы вытекает несколько предположений:

1. Если схема верна, то свободные ячейки должны заполняться недостающими фрормами (прогностический аспект).

2. Схема не должна противоречить хронологии конской сбруи (хронологический аспект).

3. Схема должна отражать культурно-исторические особенности региона (культурологический аспект).

Предложенная схема развития центральноазиатских бронзовых удил достаточно надежно проверяется тем обстоятельством, что в 42 случаях (а если учесть однокольчатые удила - в 53 случаях) представлены удила со звеньями, окончания которых имеют различные фрормы. Причем в некоторых случаях достаточно четко фиксируется какое из звеньев более потертое, изношенное, а какое прилито позднее. В отдельных случаях это определить довольно сложно. Этот процесс хотя и был довольно сложным, но имел определенную направленность. На наш взгляд, эта схема может прекрасно иллюстрировать неравномерность конструктивного развития удил, сосуществование нескольких форм в каком-то регионе, отставание одних, выдвижение других и т.д.

Выделенные по окончаниям группы удил (А-М), позволяют выделить 4 типа:

- 1 тип удил объединяет группы А-Д, которые являются различными вариантами кольцевидной, овальной формы окончания удил.

- 2 тип удил объединяет группы E, Ж, 3, и скорее всего отражает вариации подтреугольных форм.

- 3 тип удил объединяет группы И, К, является своеобразным типом со стремечковидной формой окончания звена.

- 4 тип удил объединяет группы Л и М с прямоугольным окончанием звена. 
Однокольчатые удила в предложенной схеме типологического развития начинают и заканчивают все четыре выделенных типа. С одной стороны, однокольчатые удила имитируют мягкие (ременные, веревочные) удила, скорее всего, выходящие из эпохи бронзы, с другой - они меняют стремечковидные (примерно, в VI-V вв. до н.э.) и доживают до современности.

В связи с этим представляется необходимым проанализировать однокольчатые бронзовые удила (более 150 экз.) более тщательно. По форме окончаний они достаточно четко образуют два типа:

I тип - окончание звена в виде кольца;

II тип - окончание звена в виде овала (эллипса).

Внутренние размеры окончаний удил обоих типов (как наиболее функционально значимые) весьма варьируют, встречаются они как в достаточно ранних скифских комплексах Аржан 1а-1 (Грязнов 1980, рис.12, 14, 16, 20, 23, 27), так и в относительно поздних курганах Пазырыка (Руденко 1953, табл.XXX, IX, X и др.). Поэтому для выяснения вариации материала во времени, если она действительно существует, используем следующие параметры (Рисунки 3-4):

1. Внутренний диаметр удил I типа.

2. Сочетание наибольшего (2) и наименьшего (1) внутренних диаметров окончаний удил II типа.

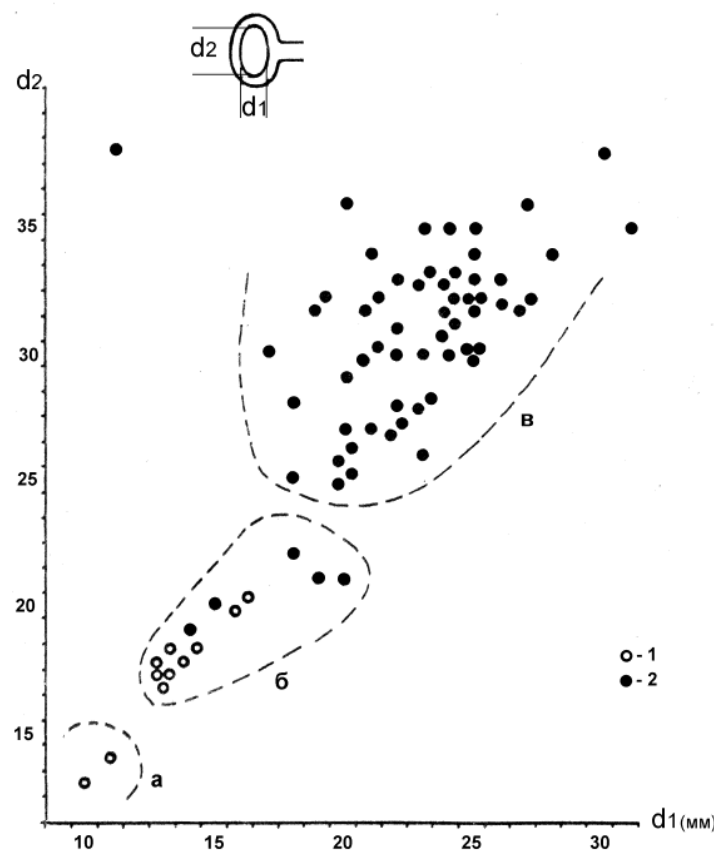

Рисунок 3. Гистограмма вариаций внутренних размеров (d 1 - наименьшего, d 2, наибольшего) эллепсовидных окончаний удил: а,б,в - дискретные группы.

I - удила из Аржана, 2 - все остальные.

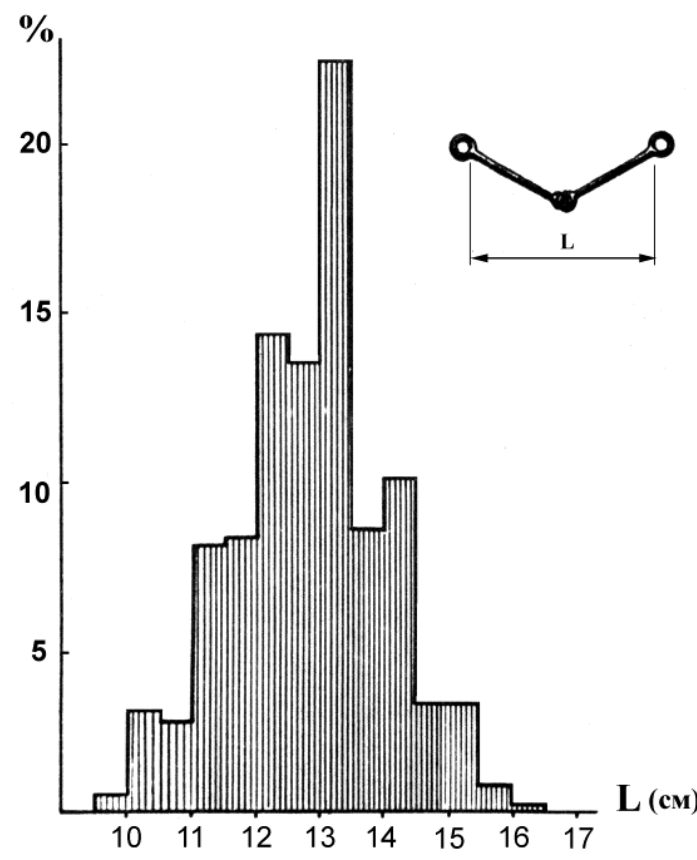

Рисунок 4. График изменения длины рабочей части удил Саяно-Алтая

(1 пол. І тыс. до н.э.). По вертикали - процентное соотношение экземпляров, по горизонтали длина рабочей части в см.

Гистограмма распределения параметра 1 обнаруживает достаточно четкие дискретные группы:

а) диаметр кольца до 10 мм;

б) диаметр кольца до 15-20 мм;

в) диаметр кольца свыше 20 мм. 
Эти дискретные группы условно можно атрибутировать как варианты а, б, в 1 типа однокольчатых удил, причем эти варианты выражают хронологическое развитие типа (вариант а - наиболее ранний, в - поздний). Подобное расширение диаметра колец удил, видимо, связано с конструктивным изменением крепления удил и псалиев.

Гистограмма сочетания 1 и 2 II типа удил (параметр 2) показывает также три относительно дискретные группы, имеющие отношение в средних пределах 0.65-0.9, но различающееся по диаметру 2:

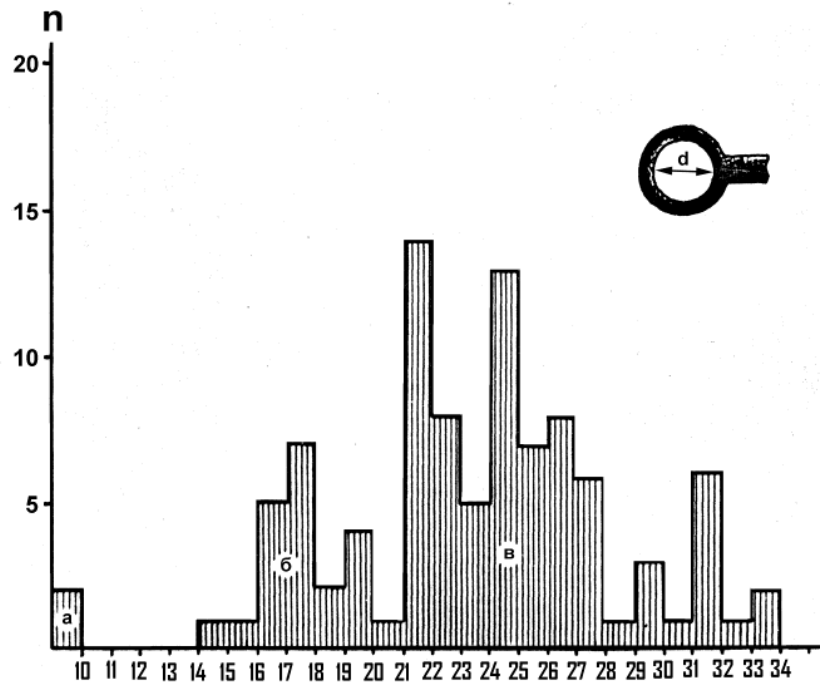

Рисунок 5. Гистограмма вариаций внутреннего диаметра однокольчатых удил: а,б,в - дискретные группы

а) сочетание 1 = 10-11 мм, 2 = 13-14 мм;

б) сочетание 1 = 13-20 мм, 2 = 17-22 мм;

в) сочетание $1=18-31 \mathrm{Mм}, 2=25-38$ мм.

Выявленные дискретные группы можно также условно считать вариантами а, б, в. II типа однокольчатых удил. По-видимому, эти варианты также показывают хронологическое развитие типа и обусловлены изменением крепления удил и псалиев. Эти посылки предстоит проверить в будущем.

Существуют еще одни уникальные удила, которые не укладываются в выделенные типы. Эти двусоставные, пока единственные для Саяно-Алтая, удила имеют на концах звеньев вместо отверстий грибовидные шляпки (Рисунок 12:5). Трехдырчатые псалии тоже с грибовидными шляпками на концах продеты сквозь среднее отверстие, но на самом деле те и другие, видимо, отлиты одновременно наглухо. Эти интересные псалии, видимо, являются своеобразным типологическим рудиментом сочетания ременных удил и костяных псалиев, зафиксированном в металле. Грибовидные шляпки на удилах могут являться стилизованными изображениями некогда завязанных ременных узлов На наш взгляд, это одно из самых древних бронзовых удил этого региона. Оно условно может представлять еще один тип.

Итак, среди удил (У) сакского времени выделяются 7 типов:

I тип - удила с кольцевидно-овальными окончаниями (варианты А, Б, В, Г, Д);

II тип - удила с подтреугольными окончаниями (варианты E, Ж, 3);

III тип - удила со стремечковидными окончаниями (варианты И, К);

IV тип - удила с прямоугольными окончаниями (варианты Л, М);

V тип - кольчатые удила (варианты A, Б, B);

VI тип - удила с эллипсовидными окончаниями (варианты A, Б, B);

VII тип - удила с грибовидными окончаниями.

Н.Л. Членова на этом же материале выделила три типа бронзовых удил: с двойными кольцами, стремявидными концами и круглыми концами (Членова 1967, С.66). В каждом из типов еще вычленяется несколько форм. В первом удила с двойными перпендикулярными кольцами, с большим внутренним кольцом, с внешним прямоугольным кольцом, с грибовидной шляпкой вместо кольца, 
с двойными кольцами в одной плоскости. Во втором - с округлыми окончаниями, с дополнительными выступами по бокам, с треугольными окончаниями, с очень крупными отверстиями или очень маленькими, с квадратными окончаниями. В третьем - простые кольчатые удила и удила украшенные «веревочкой».

Этапы развития бронзовых удил, по ее мнению, следующие: наиболее ранняя форма - удила с двойными внешними кольцами, расположенными в одной или в двух взаимо перпендикулярных плоскостях; затем - внешнее кольцо уменьшается, превращаясь в узкую прямоугольную петлю, более удобную для продевания повода; еще позднее - в связи с распространением бронзовых псалий и вытеснением ими роговых - уменьшается внутреннее кольцо; и наконец - внутреннее небольшое колечко исчезает и остается один лишь стремявидный конец. Преобразование кольца в стремявидное логически необъяснимо, и, как считает Н.Л. Членова, является прихотью мастера (Членова 1967, С.70). Правда, она все же справедливо отмечает, что предложенная ею схема не строго хронологическая, а типологическая. Замечание Н.Л. Членовой в отношении сосуществования нескольких типов удил вполне верно и подтверждается археологическими материалами (комплексы Аржан 1а-1, клад Биже в Казахстане и т.д.). Но ряд существенных моментов в ее классификации и схеме развития удил все же вызывает сомнение:

1. Не ясны признаки и принцип выделения типов и вариантов форм.

2. Предложенная хронологическая схема типов (1-2-3) в значительной степени затрудняет понимание сложной структуры развития бронзовых удил скифской эпохи, когда фиксируется одновременное развитие нескольких взаимосвязанных типов (по нашей типологии);

3. Такой признак как «строгость» удил, т.е. наличие на грызле «веревочки» выпуклых квадратиков и т.д., не всегда является хронологическим. Строгие удила всегда существовали, от момента их возникновения до настоящего времени (Иессен 1953, С.70; Урусов 1911, С.369-376). Если оформление грызл «веревочкой» типично для различных эпох, то оформление в виде выпуклых квадратиков характерно только для раннескифского времени (Грязнов 1980, отс.12:1, 26:6, 27:3; Вишневская 1975, табл.XXVI, 2-11; Маргулан, Акишев, Кадырбаев, Оразбаев, 1966, С.330, рис.24:8,9; Акишев КА, Акишев АК 1978, С.39-40).

Все вышеизложенные аспекты, на наш взгляд, необходимо учитывать при создании классификаций.

Типология псалий. Псалии, являясь вторым, наиболее значимым элементом конской сбруи, служили прежде всего для удержания удил в определенном положении во рту коня и передачи ему болевыми усилиями команд всадника. Начальный период освоения коня представлен псалиями, выполненными из органического материала (дерево, кость, рог). Впоследствии этот материал заменяется более прочным - бронзой, железом. Это, видимо, связано с тем, что на псалии приходились наибольшие усилия, часто связанные с сильными рывками. Этим же, видимо, объясняется и разнообразие форм псалиев, в котором можно усматривать не только отражение культурного многообразия, но и процесс поиска наиболее оптимальных удобных форм для псалиев. Встречаются псалии одной фооры, но выполненные из различного материала (кости, бронзы), поэтому материал при выделении признаков пока не учитывался, а будет впоследствии оговорен отдельно. Конструктивно псалии, на наш взгляд, делятся на три взаимосвязанные части: форма тулова, форма окончаний, расположение и фрорма отверстий. Соответственно и признаки выделены по этим 3 градациям. Всего выделен 21 признак. 

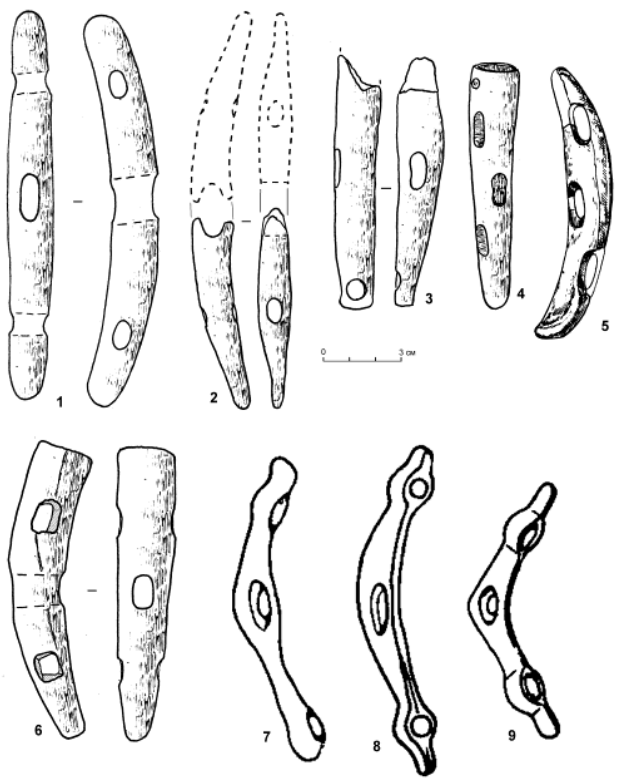

Рисунок 6. Псалии I типа:

I - Каменный Лог I (по М.Н. Комаровой), 2,3 - Еловка (по В.И.Матющенко),

4 - Устинкино, сооружение 10, яма 3 (по Д.Г.Савинову, В.В.Боброву), 5 - Торгажак (по Д.Г.Савинову),

6 - Устинкино, сооружение 10, мог. 2 (по Д.Г.Савинову, В.В.Боброву), 7-9 - Монголия (по В.В.Волкову)

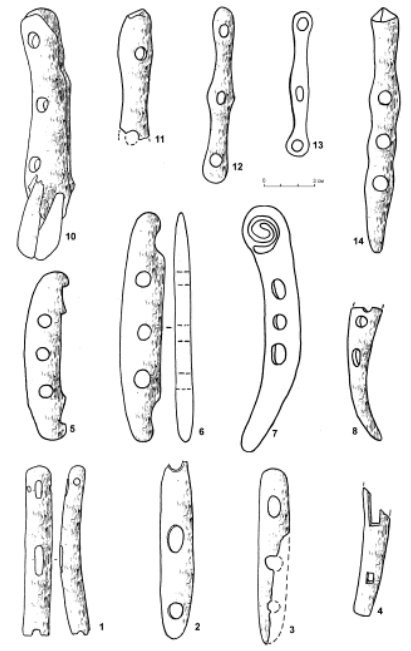

Рисунок 7. Псалии II а типа: I - Ирмень I (по М.П. Грязнову),

2 - Каменный Лог I (по М.Н. Комаровой), 3-4 - Еловка (по В.И. Магющенко). Псалии II б типа:

5 - Беллык (ММ 9533-322), 6 - Гришкин Лог, к.13, м.8 (ГЭ, 2305-100), 7 - Детлово (по Н.Л. Членовой), 8 - Большая Речка, БЕ I, зем.2 (по М.П.Грязнову). Псалии ІІ в типа: 10-13 - Аржан (по М.П.Грязнову), 14 - Усть-Куюм (по М.П.Грязнову)
А. Форма тулова: 1 - прямая, 2 изогнутая, 3 - S-видная, 4 - коленчатая, 5 - с утолщением вокруг отверстий, 6 - с выступом в центре, 7 - с петлей в центре.

Б. Форма окончаний: 8 - заостренная, 9 - тупая, 10 - грибовидная, 11 шаровидная, 12 - в виде лопасти, 13 - в виде фигурок животных (зооморфная).

В. Отверстия. Их расположение: 14 - 3 отверстия в разных плоскостях, 15 3 отверстия в одной плоскости, 16 - распределение 3 отверстий по всей плоскости равномерно, 17 - 3 отверстия смещены к центру.

Форма отверстий: 18 - круглые, 19 овальные, 20 - прямоугольные, 21 сложные псалии.

Совокупность этих признаков позволяет выделить VIII типов псалий (П) (Рисунки 6-12):

I тип - псалии прямой или слегка изогнутой формы с тремя отверстиями, распределенными равномерно по поверхности, но среднее в иной плоскости по сравнению с крайними. Отверстия бывают прямоугольные, овальные, в единичных случаях круглы. Концы в основном закруглены. Изготовлены из рога и кости (Рисунок 6).

II тип - прямой или слабо дуговидной фрормы с тремя отверстиями, распределенными равномерно по всей поверхности, вариант этого типа составляют псалии, отверстия которых смещены к центру. Отверстия разных форм, концы также обработаны по-разному.

Намечается тенденция по выделению утолщений вокруг отверстий. Можно выделить 3 варианта (Рисунок 7):

а) прямые или слабо изогнутые роговые, костяные (редко - бронзовые) псалии с тремя отверстиями, равномерно расположенными по всей длине, отверстия разных форм (прямоугольные, овальные, круглые);

б) псалии такой же фрормы, но отверстия сгруппированы к центру, вокруг них намечаются утолщения;

в) плоские псалии с круглыми отверстиями, равномерно распределенными по поверхности. Два вообще вы- 

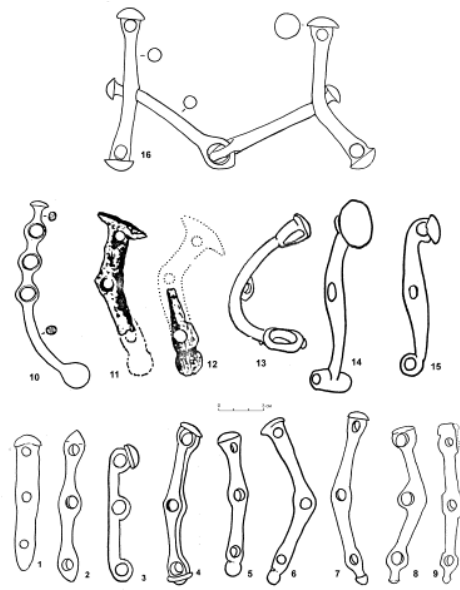

Рисунок 8. Псалии III типа:

1-2 - вариант а (Аржан, к.5; М. Минуса, ММ, 4909),

3-4, 16 - вариант б (Кольская, ГЭ, 5531-1309;

Аржан, к.26б, ТРКМ; МК, АМ ТГУ, б/н).

Псалии III в типа: 5-6 - Курту II, к.3

(по С.С.Сорокину), 7-9 - Аржан (по М.П.Грязнову),

10 - Черный Ануй (по В.И. Молодину,

В.Т.Петрину), 11 - Большая Речка, БE XIV м.21 (по М.П.Грязнову).

Псалии III г (13), III д (14-15) типов: I - Быскар (ММ, 4906),

2 - Новоселово (ГЭ 5531-1309),

3 - Абаканское (МM, 4910) полнены из челюсти коня. Псалии этого типа частично отлиты из брозы.

III тип - трехдырчатые псалии с равномерным распределением оверстий по поверхности, с заметным утолщением вокруг отверстий и грибовидными шляпками на концах. Выделяются несколько вариантов: для всех характерный признак - грибовидные шляпки (Рисунок 8):

а) прямые, с грибовидной шляпкой на одном конце, отверстия оформлены значительными утолщениями;

б) слегка изогнутой формы, с грибовидными шляпками, одностроннее выделение круглых отверстий;

в) слегка изогнутой формы с незначительным выделением отверстий, один конец грибовидный, другой - шаровидно-заостренный;

г) сильно изогнутой формы, с грибовидным окончанием, четко выделенными отверстиями, петлей в центре вместо отверстия;

д) S-образной формы, с грибовидным окончанием с одной стороны, ци-

линдрическим - с другой, центральное отверстие овальной формы.

Как правило, псалии этого типа бронзовые, хотя есть костяные (псалии варианта «а»).

IV тип - двухдырчатые псалии изогнутой формы с дополнительным уступом в центре вместо отверстия. Степень изогнутости тулова различная, отверстия круглы. Изготовлены только из бронзы (Рисунок 9:1).

V тип - У-образные или трехдырчато-коленчатые (по К.А. Акишеву). Отверстия в основном круглые, оформлены утолщениями, концы в некоторых случаях упрощенной формы в виде лопасти, а в коленной части специальные выступы для удержания удил (Рисунок 9: 2-3).

VI тип - трехдырчатые псалии с тремя отверстиями, смещенными к центру. Концы выполнены в виде утолщений (вариант «а»), либо в виде копыт лошади (вариант «б»), либо в виде грифоньих голов и др. зооморфных форм (вариант «в»). К последнему варианту условно можно отнести уникальный псалий не имеющий пока аналогий S-образной формы, с сильно смещенными отверстиями к центру, имеющему на одном конце головку грифона, с орнаментом по тулову в виде двух рядов треугольников (Рисунок 9:4-9).

VII тип - сложного вида, состоящий из кольца и через перемычку - прямоугольное окончание (Рисунок 10:1).

VIII тип - из длинных клыков кабана с отверстиями (Рисунок 10:2).

Существует еще одна серия вещей на Среднем Енисее (около 50 экз.), которую считают либо «гребенками», либо конскими «скребницами». Н.Л. Членова предположила, что эти предметы могут быть строгими псалиями. Такое заключение сделано на основе луристанских и ближневосточных аналогий (Членова 1967, С.74), т.к., действительно, аналогичные предметы найдены там совместно с удилами. В Южной Сибири эти бронзовые предметы подразделяются на 


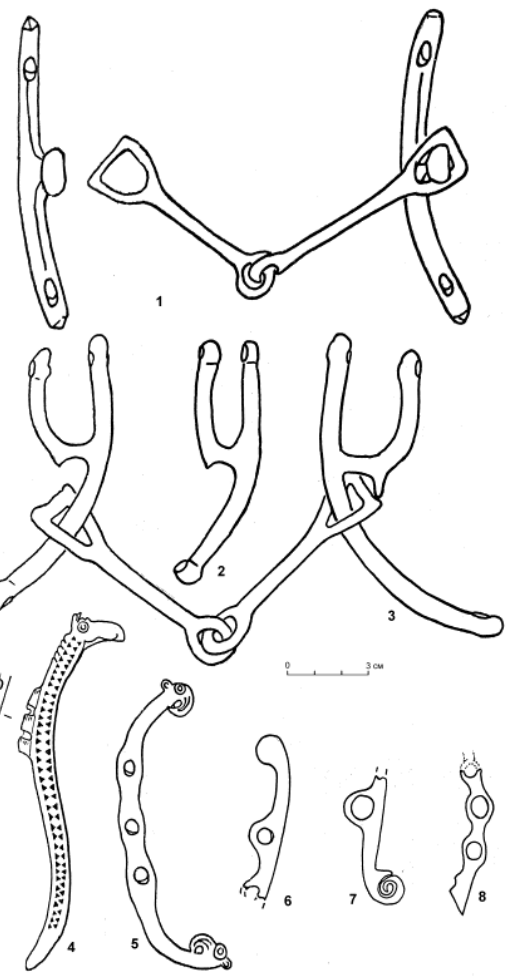

Рисунок 9. Псалии IV типа:

1 - Коксу I, к.42 (по С.С. Сорокину).

Псалии V типа: 2 - Суртайка

(по Н.Л. Членовой), 3 - Хемчик-Бом Ш, к.1,2 (по А.Д.Грачу). Псалии VI типа:

4 - Калы (ММ, 4924), 5 - М. Ничка (ММ, 4903), 6 - Потехина (ММ,4904),

7 - Б. Хабык (по Н.Л. Членовой),

8 - Потехино (АМ ТГУ, 6272-348)
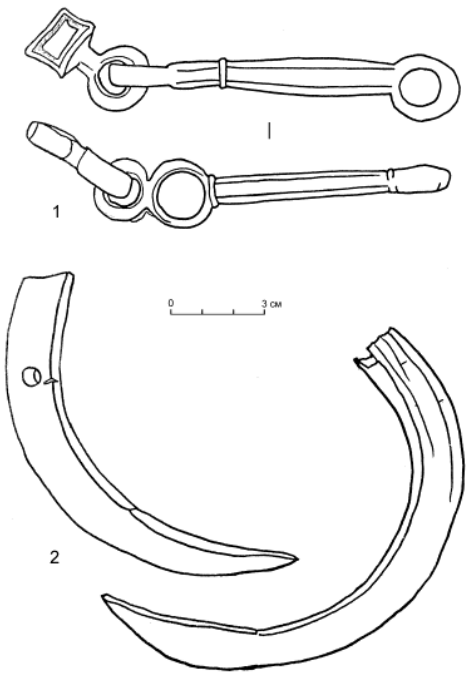

Рисунок 10. Псалии VII (I) и VIII (2-3) типов: I - Мин.котл. (АМ ТГУ, 4567), 2-3 - Аржан, к. ЗГ (по М.П. Грязнову) следующие типы (номера с учетом выделенных VIII типов, соответственно, продолжены) (Рисунок 11).

IX тип - бантообразные ажурные пластины с продольным отверстием в средней части и шипами на одной из сторон. Выделяются несколько вариантов:

а - фигурно-овальной формы, иногда с изображением на одной стороне различных завитков, головок «грифонов»;

б - ромбовидной формы.

X тип - ажурные пластины различных геометрических форм с шипами с вырезами для продевания грызла удил и небольшими отверстиями для крепления ремешков на одном из концов. Варианты: а - прямоугольной формы; 6 - прямоугольной; в - подтреугольной; г - овальной.

XI тип - ажурные пластины с шипами разных форм со стержнем, в котором находится небольшое отверстие. В некоторых случаях на стержне имеется предохранительный уступ. Варианты: а - трапециевидной формы; б - М-образные; в - Т-образные.

Необходимо отметить, что шипы не острые, а тупые, характерные для такого типа псалиев. По мнению К.Ф. Смирнова, псалии IX типа прикреплялись к удилам так, что не касались морды коня, а при натягивании повода поворачивались на девяносто градусов и шипами давили на морду (Членова 1967, С.74, рис.4). Реконструкция функционального назначения XI типа строгих псалиев, приведенная там же, на наш взгляд, не совсем верна. Кольчатые удила не совсем подходят для этой формы псалиев, скорей всего ей могут соответствовать двукольчатые удила, то есть удила с внутренним маленьким отверстием (3-6 уровни всех типов данной классификации удил). Экспериментально нами установлено, что стержень псалиев XI вида свободно входит в это отверстие удил, причем в некоторых случаях на стержне псалиев есть специальный предохранительный уступ. В некоторых случаях потертости на плоских гранях этих псалиев полностью совпадают с внешними размерами внутренних 
колец двукольчатых удил. Трассологический анализ полностью подтверждает такое расположение удил (Б4, B4, Е3, И3) и псалиев (XI a, б). Эти предметы в основном найдены в Минусинской котловине, всегда случайно и отдельно от удил, так что трактовка их функционального назначения, как псалиев, весьма вероятна, но до находки их в сочетании с удилами остается гипотетичной. Если в дальнейшем эти предметы будут все же найдены в комплексах с удилами, то удила вышеуказанных групп (с дополнительными маленькими отверстиями) с такими псалиями можно трактовать, как узду специального назначения, используемую для интенсивной выездки лошади.

М.П. Грязнов проследил по материалам кургана Аржан 1 принцип крепления псалиев к удилам: в этот период существовало два способа крепления (Рисунок 12).

Обоймы для ремней (ОДР) следующая функционально значимая категория сбруи. По своему назначению) они подразделяются на несколько групп; развилки-двойники для суголовых ремней, обоймы для перекрестия ремней, обоймы для украшения ремней, обоймы для удерживания ремня.

Развилки-двойники (РД) предназначены для соединения двух ремней, идущих от псалиев, далее, после соединения в виде узла, суголовый ремень уже идет один. Эти обоймы-двойники общепринято относить к позднескифскому времени (V-III вв. до н.э.), так как традиционно считается, что для раннескифского времени характерно троение ремней благодаря применению тредырчатых псалиев (Членова 1967, С.78). Находки деталей узды в погребальных памятниках V-III вв. до н.э. в Туве (могильник у с.Туран, курган 34; Саглы-Бажи II, курган 4 и др.), в памятниках Алтая и Запад-
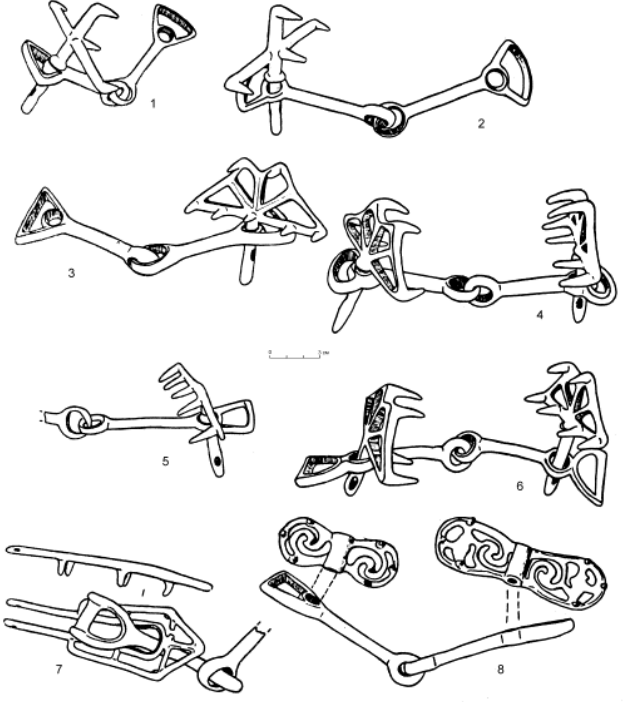

Рисунок 11. Вероятные комплекты удил и псалий с шипами IX (8), X (7) и XI (1-6) типов: I - удила, Мин.котл. (ММ, 4854); псалий, Белоярское (ММ,4949), 2 - удила, Мин.котл. (ММ, 4846); псалий, Тесинское (ММ,4948), 3 - удила, Беллык (ММ, 4860); псалий - Мин.котл. (ММ, 4928), 4 - удила, Мин.котл. (ММ, 4855); псалий, Мин.котл. (ММ, 4927, 4930), 5 - удила, Мин.котл.. (ММ, 4816); псалий, Лугавское (ММ, 4947), 6 - удила, Мин.котл. (ММ, 4853); псалии, Мин.котл. (ММ, 4932; 4931), 7 - удила, Беллык (ММ, 4841); псалий, Биря (ММ, 4963),

8 - удила, Мин.колл. (ММ, 4840); псалии, Батени (ММ, 4965), В.Коя (МM, 4966)

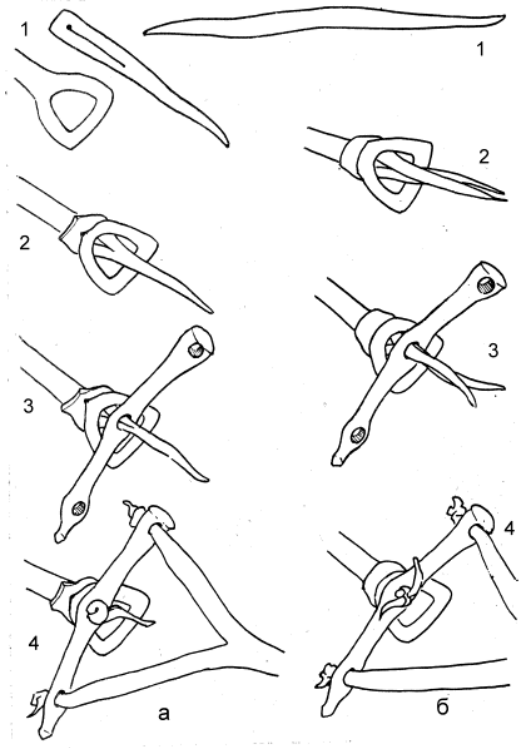

Рисунок 12. Два варианта крепления трехдырчатых поалиев к удилам в аржанской узде (по М.П. Грязнову) 
ной Сибири (Быстровка 1 и др.) действительно позволяют говорить о распространении этих обойм в комплектах конской узды и о достаточно ясно выраженном их функциональном назначении. Подобная специализация обойм, видимо, обусловила и их чрезвычайно лаконичное внешнее оформление - эти обоймы В-образной фрормы, без лишних деталей, обычно выполнены в металле.

Для раннесакского времени (IX-VI вв. до н.э.), видимо, обоймы-двойники также характерны, хотя фрорма их несколько иная.

Это предположение основывается на двух моментах:

1. Материалами кургана Аржан 1-1 доказано, что для этого периода наряду с троением нащечных ремней существовало двоение, так как трехдырчатый псалий привязывался через среднее отверстие к удилам наглухо (Грязнов 1980, С.27, рис.1,2; С.30, рис.16:2, 4, 6 и сл.). М.П. Грязновым даже высказано мнение, что троения нащечных ремней вообще не было, и для уздечек СаяноАлтая характерно двоение ремней (на скульптурном изображении головы коня из Аржан 1а-1 прекрасно видно, что нащечных ремней было два. Для других территорий (напр. Казахстана) эта точка зрения пока проблематична. Ассирийские рельефы IX века до н.э. свидетельствуют о наличии тройных нащечных ремней (Anderson 1961, pl. 1,3,4a), а начиная с VIII-VII вв. до н.э. их становится два (Anderson 1961, pl. 5,6,9, II). Является ли это особенностью ассирийской узды, или такая система была распространена шире, пока сказать трудно, так как тройные нащечные ремни в Ассирии использовались для бантообразных псалиев (Рисунок 10).

2. Наличие в курганах Аржан 1a-1 значительной серии двухдырчатых бляшек из клыков кабана и коня, а также рас-

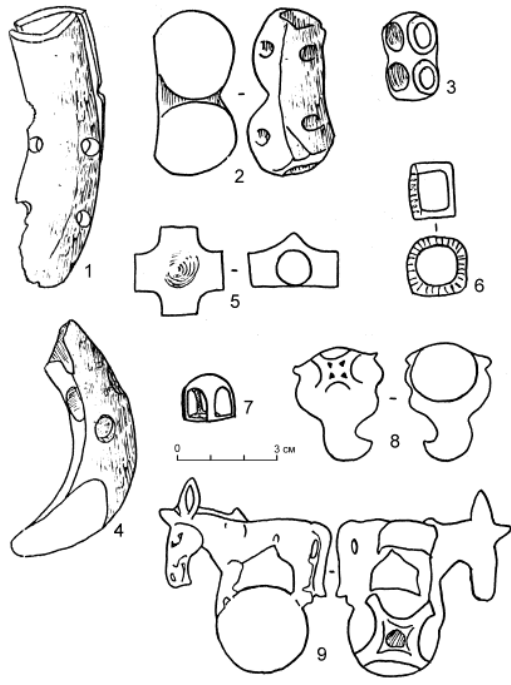

Рисунок 13. Обоймы-двойники (ОД 1-3) и обоймы.дпя перекрестья ремней (ОПР, 4-9): 1-2 - Аржан (по М.П. Грязнову), 3 - Знаменка (ГЭ, 5531-1332), 4 - Аржан (по М.П. Грязнову),

5 - Юдино, МК (АМ ТГУ, 6272-130), 6 - Юдино (АМ ТГУ, 6272-128),

7 - Ортаа- Хем, к. 11 (по А.Д. Грачу), 8 - Мин.котл. (ГЭ, 331-9), 9 - Мин. котл. (ГЭ, 3975-316) положение их в камере 1, 2, 26Б и 37 позволяет предположить, что в некоторых случаях они использовались не только как украшения узды, но и в качестве обоймдвойников.

Среди обойм-двойников по внешней форме, расположению и размерам р отверстий (5 мм и более) можно выделить два типа (Рисунок 11):

I тип - обоймы слегка изогнутой фрормы в виде клыка со сточенными краями;

II тип - восьмеркообразные в плане бляшки, так называемые, бинарные.

Все они изготовлены из клыков, только один экземпляр II типа из Минусинской котловины (дер.Знаменка) выполнен из бронзы (ГЭ 5531-1332).

Обоймы для перекрестья ремней являются следующей категорией элементов конской узды, функциональное назначение которой достаточно ясно выражено во внешнем виде. Довольно часто они не употреблялись и вместо них использовали наглухо закрепленные узлами бляхи, либо подвески.

По внешней фрорме, с учетом конструк- 
тивных особенностей оформления этих предметов, обоймы (ОПР) достаточно четко можно разделить на четыре типа (Рисунок 13):

I тип - в виде клыка (кабана или коня) о двумя круглыми отверстиями, просверленными перпендикулярно по отношению друг к другу. Причем в одних случаях это был действительно настоящий клык, а в других - его имитация. На некоторых перекрестниках отверстия выполнены на небольшом расстоянии друг от друга.

II тип - в виде перпендикулярно перекрещивающихся трубочек с центральным круглым отверстием в нижней части. В верхней части либо находится еще одно отверстие, либо конусовидный выступ.

III тип - в виде кубика с круглыми отверстиями в боковых гранях, а иногда и во всех (примером может служить обойма из Минусинского края, дер.Юдино АМ ТГУ, № 6272-128). В некоторых случаях лицевая грань оформлена насечками, спирально, либо резким кругом.

IV тип - в виде двух кружков соединенных четырьмя столбиками. Лицевая грань обычно выпуклой формы, в противоположной - отверстие круглой, квадратной либо крестообразной формы. Этот тип по оформлению лицевой грани подразделяется на три варианта:

A - обоймы простой формы, лицевая грань которых в виде выпуклого кружка;

Б - лицевая грань офрормлена в виде «запятой» и асимметричного листа;

В - лицевая грань зооморфной формы, в виде зооморфных фригур: грифонов, куланов, оленей и т.п.

Следующими элементами конской уздечки являются налобные, нащечные бляхи, подвески и различные пронизки. Эти категории вещей достаточно разнообразны по внешнему оформлению и служили в основном для украшения узды, то есть выполняли эстетическую функцию. Можно предположить и более сложную семантику этих вещей, например, выполнение фрункции «оберегов», или индикаторов определенного социального положения и т.д.

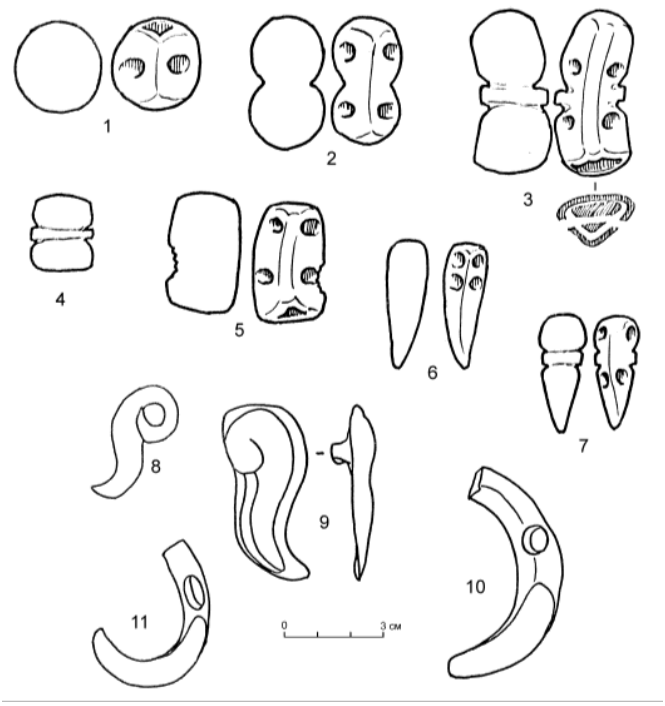

Рисунок 14. Нащечные бляхи (НЩБ):

I - І тип (Аржан), 2 - II А (Аржан),

3 - II Б (Аржан), 4-5 - II В (Аржан),

6 - II Г (Аржан), 7- II Д (Аржан),

8-9 - III тип (Лугавское, ММ 9307; Елунино, АГУ, 309), 10-11 - IV тип (Аржан; Мин.котл., ГЭ 331-5). 1-7, 10 - по М.П. Грязнову

Нащечные бляхи (НЩБ) и подвески (около 480 экз.) по внешней форме, количеству и расположению отверстий разделяются на несколько типов (Рисунок 14):

I тип - круглые бляшки с одним отверстием на внутренней стороне. Эти бляшки (в диаметре 2 см и более) выполнены либо из рога, либо из бронзы. В отличие от роговых, у которых отверстие просверлено в тулове бляшки, бронзовые на внутренней стороне имеют петлю.

II тип - бинарные бляшки с двумя отверстиями, выполненные, в основном, из клыка кабана. Подразделяются на четыре варианта:

A - простые бинарные бляшки без дополнительных выступов;

Б - бабочковидные бляшки (по М.П. Грязнову) с четко выраженным выступом в центральной части, делящим бляшки пополам, обе стороны по- 
лучаются симметричными. В некоторых случаях имеется дополнительное отверстие на одной из граней, перпендикулярное двум другим отверстиям;

В - аналогичные бабочковидные, до края подрезаны так, что в плане имеют фрорму прямоугольника - прямоугольные бляшки;

Г - подтреугольные бляшки с двумя просверленными отверстиями;

Д - бляшки, представляющие собой сочетание; верхняя часть круглая, нижняя - подтреугольная, иногда отделенная выступами. Обычно два отверстия, либо параллельные, либо перпендикулярные.

III тип - бляшки в виде запятой, имеющие с обратной стороны петлю для подвешивания. В большинстве случаев выполнены в бронзе. На лицевой части имеются рельефные углубления, которые вписываются в общую форму бляшки.

IV тип - просверленные клыки коней и кабанов, или их имитации в бронзе (примером могут служить бляшки из Красноярского края - ГЭ, 331-5, 55311377). Этих подвесок довольно много, только в комплексах Аржан 1а их насчитывается более 250 экземпляров.

Видимо, для сакского времени этот вид конских украшений был весьма популярен и использовался для различных целей, но в основном для украшений различных ремней узды (нащечных, налобных и т.д.). А нахождение клыков коней или кабанов вместе в большом количестве в нескольких камерах Аржан 1a-1 (Грязнов, 1980, С.26,36 и сл.) позволяет предполагать, что они украшали нагрудные ремни жеребцов. Во всяком случае, изображения аналогичных подвесок и бляшек (вида бинарных) на нагрудных ремнях у коней зафиксированы на ассирийских рельефрах IX-VII вв. до н.э. (Anderson 1961, pl.4,5).

Налобные бляхи и подвески (НББ), как было указано выше, часто имели те же фрормы, что, например, и нащечные. По-видимому, применение их не было строго регламентировано, хотя специфические формы для налобных ремней существовали. В кургане Аржан 1 найден налобник в виде большой круглой бляхи из золота, центральная часть которого - выпуклый серебряный кружок (Грязнов 1980, рис.12, 6); возможно, также использовались найденные здесь же в 1 камере еще три золотых кольца с утраченными серебряными кружками (Рисунок 15: 1-3).

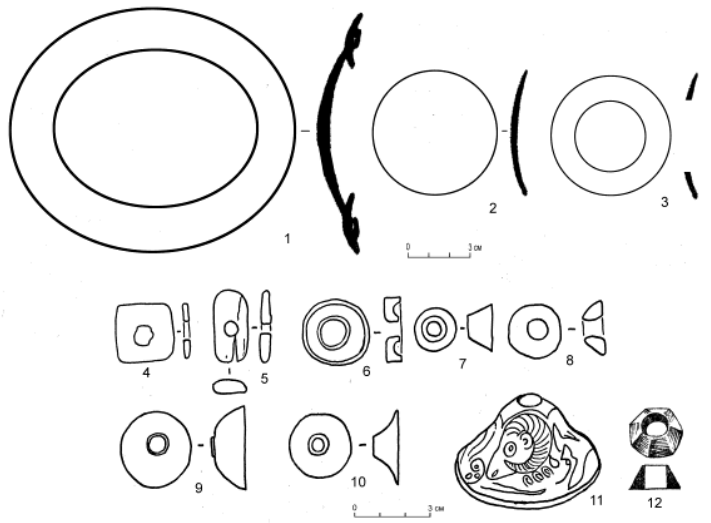

Рисунок 15. Налобные бляхи (НБ) и затылочные обоймы (30): 1-3 - НБ (Аржан), 4 - 12 - 30: І А тип (Аржан), 5 - І Б тип (Аржан); б - I В тип (Аржан), 7 - II тип (Лугавское, ММ 8762), 8-9 - III А тип (Аржан;

М.Минуса) 10 - ІІІ Б тип (р.Тесь и Аи, ГЭ 5531-1348), 11 - III Б тип (Мин.котл., по М.П. Завитухиной), 12 - IV тип (Мин.котл., ГЭ 5975-340).

Предметы из Аржана даны по М.П. Грязнову
Затылочные обоймы служили для закрепления затылочного ремня оголовья, или ремня ошейника. После надевания узды на морду коня, затылочные ремни протягивались в отверстие обоймы, и после этого завязывался узел (Рисунок 15: 4-11). Этим осуществлялась подгонка узды по длине морды коня. В некоторых случаях, когда узда делалась специально для какого-то конкретного коня, подобные обоймы не использовались. Иногда они могли использоваться не только для закрепления ремней оголовья, но и для закрепления начельника, или султанчика, который существовал в основном у колесничих коней (Anderson 1961, pl. 1,5,6,9).

По форме затылочные обоймы 
делятся да четыре типа (Рисунок 15):

I тип - квадратные или овальные, круглые пластины (4x1.5см; $2.5 \times 2.5$ см) с одним отверстием в центре. Этот тип имеет три варианта:

А - квадратные пластины, выполненные либо из бронзы, либо из кости (рога);

Б - овальные пластины, изготовленные из тех де материалов;

В - круглые пластины из тех де материалов, иногда имеющие на лицевой стороне рельефные ребра (Аржан 1-1, камера 26б).

II тип - усеченно-конические круглые обоймы (2-2.5 см) с отверсти ем в центре (до 1 см). В основном изготовлены из бронзы.

III тип - конические круглые обоймы с отверстием в центре. Разделяются на два варианта:

A - с выпуклыми гранями, диаметр 2-5 см.

Б - с вогнутыми гранями, диаметр 3-6 см.

На тех и других по краю встречается орнамент в виде ямок, насечек, бугорков. На некоторых внешние грани имеют рельефные изображения зверей, представляющие иногда целые сюжеты.

IV тип - многогранники (5 и более граней).

Обоймы II-IV типов часто называют ворворками для кистей под шеей лошади, но, как правильно полагает М.П. Грязнов, они служили для крепления ремня на затылке лошади (Грязнов 1950, С.29, рис.9; С.55, рис.20). В пользу этой точки зрения свидетельствуют два обстоятельства:

1. Эти обоймы (ворворки) найдены в комплексах скифского времени (Пазырык, Уйгарак, Молчановка, Блюменфельд и др.) в таком сочетании, которое позволяет реконструировать их в качестве затылочных обойм;

2. На ассирийских рельефах на ошейниках под мордой коня изображены не обоймы-ворворки, а колокольчики, отличающиеся от них по размерам и пропорциям (Schmidt 1957, pl.59, 83, 84, 99).

Украшения для ремней (УР), кроме указанных выше (нащечные подвески - типы I-IV данной классификации), представлены еще двумя довольно распространенными типами (Рисунок 16):

I тип - обоймы в виде простых бронзовых колечек, которые равномерно распределялись на ремнях оголовья и повода. Подразделяются на два варианта:

А - колечки, имеющие сечение в виде овала или полукруга.

Б - колечки, имеющие подтреугольное сечение.

II тип - желобчатые бляшки, служившие либо для украшения нагрудных ремней, либо в качестве застежек. Изготовлялись из различного материала: дерева, рога, кости, камня (антигорита), бронзы. По внешней Форме, количеству и размерам желобков различаются три варианта:

А - трехжелобчатые бляшки с одной плоской стороною и четко выраженными желобками;

Б - желобчатые бляшки с двумя слабо выраженными желобками по краям, а в средней части вместо желобка - четыре бугорка, равномерно расположенные по всей окружности тулова;

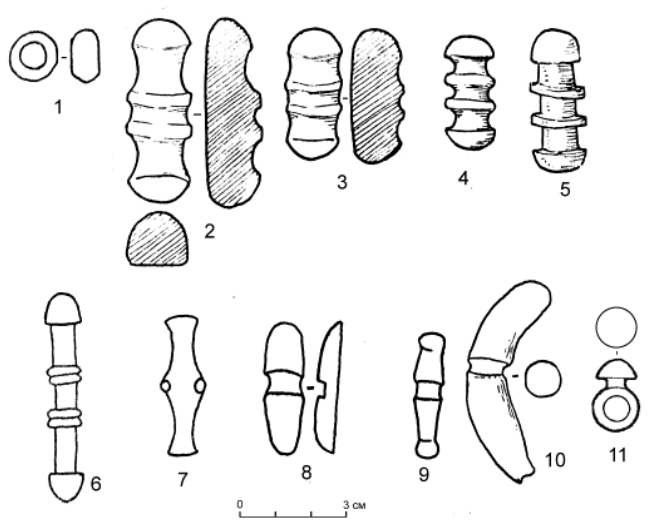

Рисунок 16. Украшения для ремней (УР): I - І тип (Солонечная, к.2 - по С.И.Руденко), 2-5 - II А тип (Аржан), 6 - II А тип (Бейское, ММ 8446), 7 - II Б тип (Анаш, ММ 8448),

8-9 - II В тип (Аржан; Сабинское, ММ 8443), 10 - II Г тип (Аржан), 11 - II Д тип (Суртайка). Предметы из Аржана даны по М.П. Грязнову 

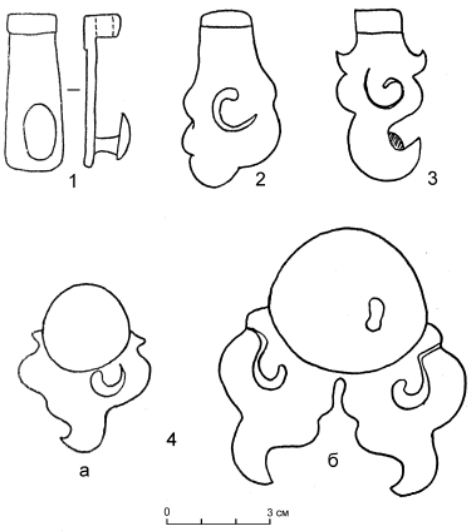

Рисунок 17. Застежки для ремней (ЗР):

$$
\text { I - І тип (Мин.котл., ГЭ 33І-11), }
$$

2-4 - II тип (Калы, ММ 8418; Б.Ничка, ММ 8411 Мин. котл., ММ 9100)
В - одножелобчатые бляшкизастежки в виде прямого стерженька с утолщением по краям, либо без них;

Г - одножелобчатые бляшкизастежки дугообразной Формы, концы слегка заострены.

Д - колечки с грибовидной шляпкой.

Последние два варианта $(B, \Gamma)$ могли еще применяться в качестве застежек подбородного ремня, что прекрасно видно на изображении узды рельефа из Персеполиса (Anderson 1961, pl.30).

Застежки для ремней, представляют собой бронзовые подпрямоугольные или усеченно-каплевидные (усложнение за счет завитков, прорезей) пластины, имеющие с обратной стороны на одном крае петлю для закрепления застежки и шпенек на другом краю для закрепления ремня. Судя по размерам ремня, на котором крепилась застежка (10-15 мм), он принадлежал к ремням оголовья и, по-видимому, застежки использовались для подбородного ремня, как и варианты В и Г второго типа вышеуказанных украшений для ремней. Полифункциональность - достаточно типичное явление для различного рода застежек.

По внешней форме среди застежек для ремней (ЭР) выделяются два типа (Рисунок 17):

I тип - застежки подпрямоугольной фрормы

II тип - застежки усложненно-каплевидной фрормы с дополнительными завитками и прорезями. На некоторых шпеньках имеются копытообразный символ.

Довольно часто в узде вообще не использовали эти пряжки, а завязывали узлы (см., например, Грязнов 1941, рис.92; Руденко 1953, С.154, рис.93а).

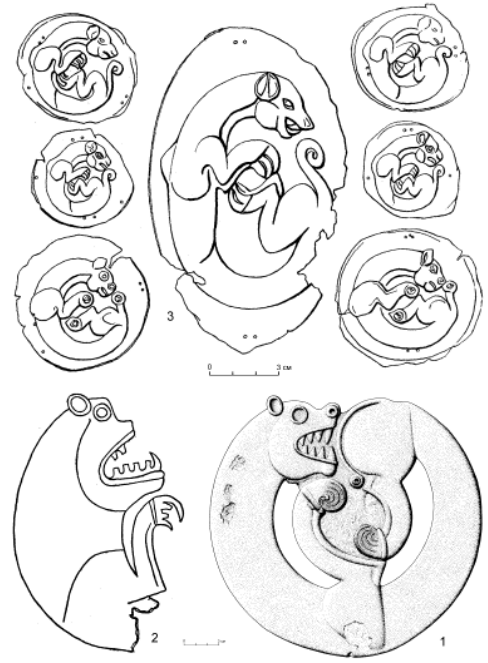

Рисунок 18. Нагрудные украшения (НУ-1-2) и налобные украшения (НЛ-3): 1 - Монголия (по Д. Майдар), 2 - Аржан (по М.П. Грязнову), 3 - Майэмир (по Л.Л. Барковой)

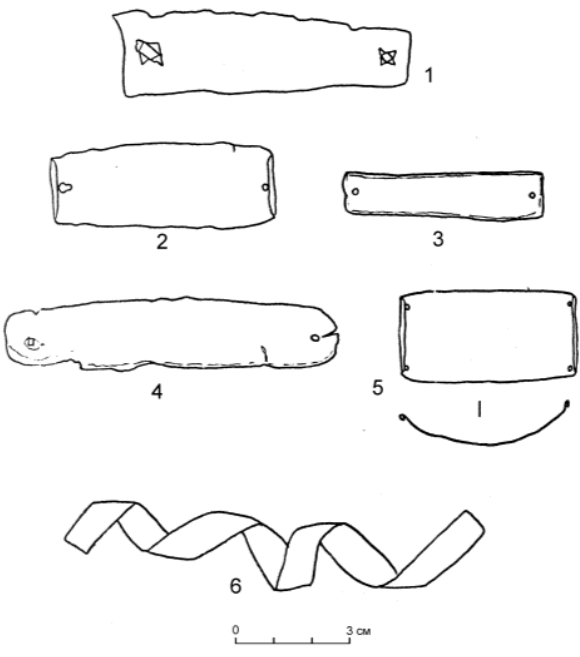

Рисунок 19. Нахвостники Аржана (по М.П. Грязнову). Номера на рисунках соответствуют номерам типов. Все-золото 


\section{Типология элементов сбруи}

Нагрудное украшение (НУ) представлено великолепной бронзовой бляхой в виде свернутого в круг кошачьего хищника, диаметром 25 см (Грязнов, 1980, С.27, рис.15,4). Если остальные украшения полифункциональны, то эта бляха, видимо, сделана специально для нагрудного ремня; обломок аналогичной бляхи, стилистически более архаичной, случайно найден случайно в Монголии (Майдар, 1981, С.32-33). Петли на обратной стороне позволяют реконструировать способ крепления бляхи на груди коня (Рисунок 18).

Нахвостники $(\mathrm{H})$ пока обнаружены для этого времени только в кургане Аржан 1-1. Все они выполнены из листового золота (кроме VI типа). По фрорме исполнения и отверстиям для их крепления, они под разделяются на шесть типов, что вообще соответствует классификации М.П. Грязнова (Рисунок 19):

І тип - длинные прямоугольные полоски (7-8 см) с двумя отверстиями по краям. Отверстия ромбической фоормы.

II тип - длинные прямоугольные полоски (до 6 см) с двумя загнутыми.

III тип - краями, двумя неболь-шими круглыми отверстиями по краям.

IV тип - длинные прямоугольные полоски (до 6 см) с загнутыми краями со всех сторон и двумя маленькими круглыми отверстиями.

$\mathrm{V}$ тип - длинные полоски (до 9 сад) с овальными краями и квадратными маленькими отверстиями по краям.

VI тип - прямоугольные полоски (до 5 см) с двумя закругленными краями и четырьмя маленькими круглыми отверстиями по краям.

VII тип - длинная узкая медная полоска, свернутая спиралью (около 30 см).

Блок чумбура или правильнее оказать - блок повода для чумбура (БИЧ), представляет собой небольшую пряжку в виде кольца или овала с прямоугольной петлей, которая часто имеет дополнительные выступы для удержания ремня в определенном положении. Эти пряжки выполнены из бронзы, кости, в более позднее время иногда встречаются из дерева. В некоторых случаях вместо них используют узел (Грязнов 1941, рис.92).

Часто эти пряжки путают с подпружными, и поэтому для выявления четких критериев, по которым можно их различить, составлена гистограмма. Сопоставлялись размеры отверстий для ремней, которые наглухо крепят пряжку (L1) и в которые продевался либо чумбур, либо подпруга (L2). B результате сравнения размера отверстий для ремней выявляются три дискретные группы (Рисунок 20-21):

$$
\begin{array}{ll}
\text { I - L1 }=14-26 \text { мм; } & \text { L2 }=39-42 \text { мм; } \\
\text { II - L1 = 13-27 мм; } & \text { L2 }=24-35 \text { мм; } \\
\text { III - L1 = 8-14 мм; } & \text { L2 }=13-23 \text { мм. }
\end{array}
$$

Первые две группы с отверстиями для широких ремней относятся к подпружным пряжкам.

Пряжки третьей группы, скорее всего, являются блоками для чумбура. Эти блоки делятся на два типа:

I тип - пряжки с овальными отверстиями. По форме легли для крепления к пряжке делятся на два варианта:

А - с подпрямоугольной петлей и дополнительными выступами по краям;

Б - с подтреугольной петлей и дополнительными выступами по краям;

II тип - пряжки с круглыми отверстиями. Аналогичное деление на варианты и в этом типе:

А - с подпрямоугольной петлей для крепления ремня. На некоторых пряжках дополнительные выступы для удержания ремня в определенном положе- 
нии незначительны, что является отражением, на наш взгляд, типологического развития;

Б - с подтреугольной петлей и слабо выраженными дополнительными выступами по краям;
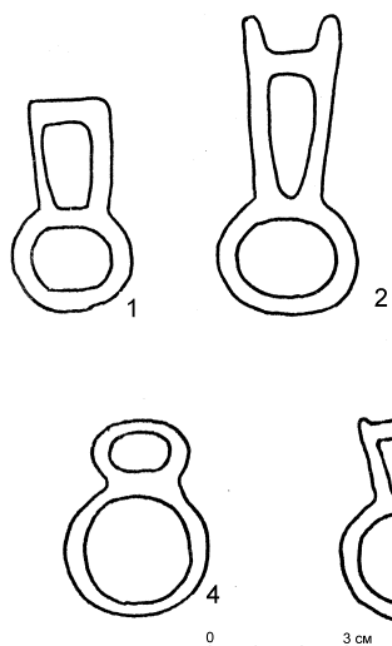
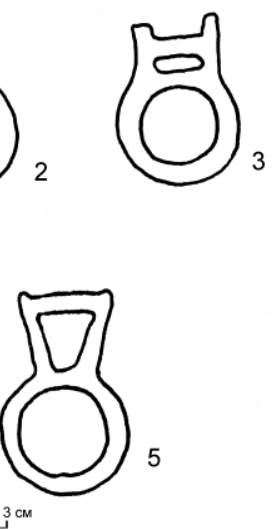

Рисунок 20. Блоки повода для чумбура (БПЧ):

I - І А тип (Каменка, ММ 8338),

2 - І Б тип (В.Коя, ММ 8327),

3-4 - II А тип (Башадар II, по С.И.Руденко; Абаканское, ГЭ 553І-ІЗІ5),

5 - II Б тип (Бондарево, ММ 8339)

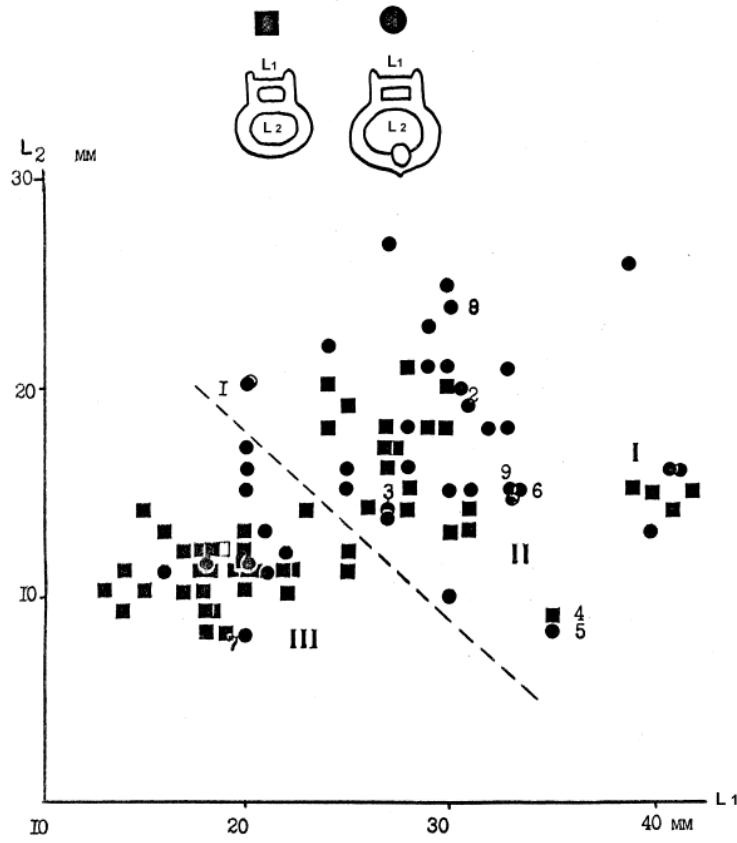

Рисунок 21. Корреляция крепежного (L1) и подпрукного, ременного (L2) отверстий у подпружных пряжек и блоков для чумбуров: I - Аржан, 2 - Кок-су I к.42, 3 - Солонечная к.2, 4-5 - Алды- Бель I к.21, 6 - Туэкга I, 7-8 - Туэкта 2, 9 - Башадар 2. Примечание: I-III варианты по количественным критериям

Подпружные пряжки (ПП) обычно парные (со шпеньком - ППш и без него ППб), судя по нахождению их в непотревоженных комплексах, как правило, располагались с обеих сторон седла или седельных подушек (Сорокин 1974, С.66, рис.21; Вишневская 1973, С.17, рис.7; С.20, рис.9; С.24, рис.12; С.25, рис.13 и сл.). Скорее всего (на некоторых планах могил это прекрасно видно), обе пряжки наглухо крепились к седельным подушкам; со шпеньком - слева, без него - оправа, а подпруга закреплялась на правой пряжке, шла через живот коня и натягивалась на шпенек левой.

Пряжки со шпеньком по внешней Форме, размерам отверстий и расположению шпенька делятся на пять видов (Рисунок 22):

І тип - пряжки в виде стремечка без дополнительных отверстий для крепления ремня, шпенек в виде бугорка с перехватом, ширина ременного отверстия 19-20 см.

II тип - пряжки в виде ажурной спирали; шпенек в некоторых случаях имеет копытообразный символ; ширина ременного отверстия достигает 42 мм.

III тип - пряжки с круглым отверстием. По Форме и оформлению дополнительного ременного отверстия выделяются три варианта:

А - дополнительный выступ на противоположной грани от шпенька, ширина отверстия до 57 мм; 
Б - прямоугольное отверстие для крепления ремня как с дополнительными выступами по бокам, так и без них, шпенек либо выступает вертикально, либо отогнут наружу L1 = 8-25 мм, L2 = 20-30 мм;
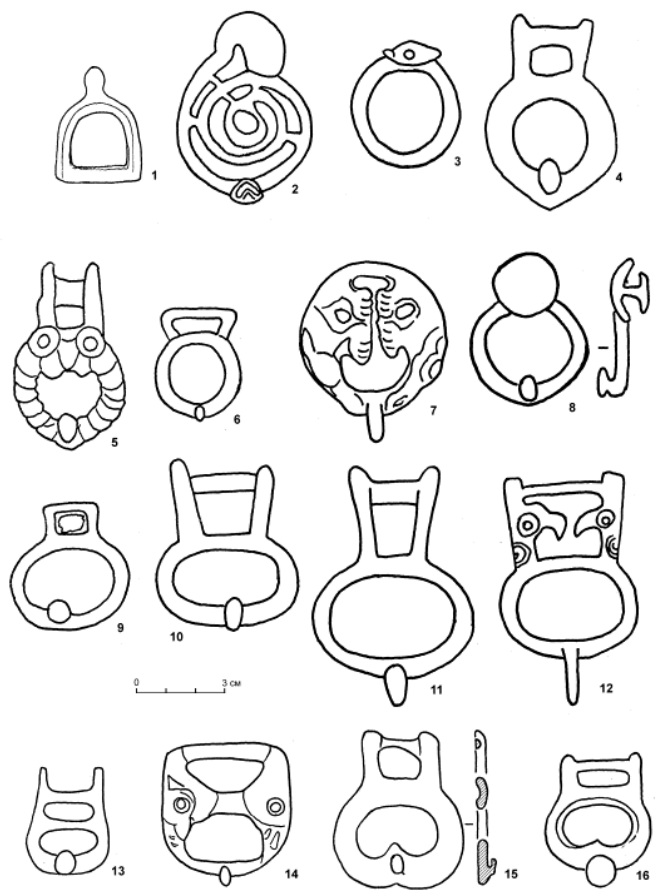

Рисунок 22. Подпружные пряжки со шпеньком (ППш): I тип - 1 (Аржан), II тип - 2 (Хемчик-Бом Ш, к.1,2), III А тип - 3 (Хемчик-Бом 01, к Л,2), III Б тип 4,5,6 (Солонечная, к.2, МАЭ 2406; Мин.котл., ГЭ, СИ 38-49; Алтайское, Мин.котл., ГЭ 553І-І32І), III В тип - 7 (Мин.котл., ГЭ 5531-1323), IV A - 8 (Кок-су I, к.42, ГЭ), 1У Б - 9,10 (Алды-Бель І, к.21; Батени, MM 8360), IV В тип - 11,12 (Мин.котл., ММ 8365;

Кавказское, MM 8364), IV Г тип - 13-14 (Лепешкина, ММ 8348; Кавказское МК, ГЭ 1296-

158), V А тип - 15-16 (Томск, АМ ТГУ 4196; Башадар 2, ГЭ)<smiles></smiles><smiles></smiles><smiles>C1=CC=C2CCCC=C(C=C1)C2</smiles><smiles>C1=CC=CC2C=CC=CC(=CC=C1)C2</smiles>

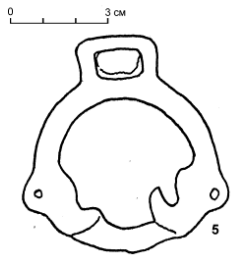<smiles></smiles>
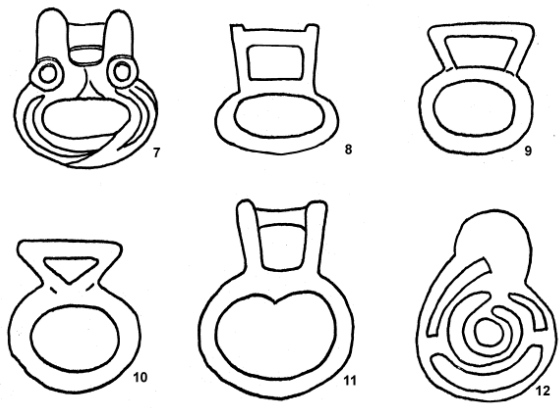

Рисунок 23. Подпружные пряжки без шпеньков

(ППб): І тип - 1, 2 (Хемчик-Бом Ш к.1,2; Анашкина, ГЭ 553І-І3І7),

II А тип - 3 (Коксу Г к.42, ГЭ),

ІІ Б тип - 4, 5 (Солонечная, МАЗ 2406;

Чаны МК, АМ ТГУ 4859),

II В - 6 (Городок, ММ 8330),

III А тип-7-8 (Алды-Бель I к.21; Корпик, ГЭ 5531-1316), III Б тип-9-10 (Бейское, ГЭ 553І-І3І2; Уты, ММ 8329),

IV тип - 11 (Батени, ММ 8321),

V тип - 12 (Хемчик Бом Ш к.1,2)

В - дополнительное отверстие вписано в общий круг, шпенек отогнут наружу, есть случаи украшения краев зооморфными рельефами, L1 = 16-21 мм, $\mathrm{L} 2=25-53 \mathrm{Mm}$.

IV тип - пряжки с овальными отверстиями и разным оформлением дополнительного отверстия для крепления самой пряжки. Выделяются четыре варианта:

А - дополнительное отверстие для крепления пряжки в виде петли с противоположной стороны от шпенька, сам шпенек отогнут внутрь, L1 = 20 мм, L2 = 30 мм;

Б - дополнительное отверстие подпрямоугольной Формы, по краям дополнительные выступы, шпенек отогнут внутрь, L1 = 15-21 мм, L2 = 29-41 мм;

B - аналогичные пряжки, только шпенек в виде острия отогнут наружу, в некоторых случаях отсутствуют дополнительные выступы, но присутствует зооморфное украшение по краям, L1= 11-26 мм, L2 = 18-21 мм;

Г- дополнительное отверстие подпрямоугольной формы, вписанное в общую Фигуру пряжки, иногда отсутствуют дополнительные выступы, шпенек отогнут, L1 $=17-22 \mathrm{Mm}, \mathrm{L} 2=24-30 \mathrm{~mm}$. 
V тип - пряжки с сердцевидным отверстием, шпенек отогнут внутрь. В некоторых случаях представлена стилизованная зооморфность по граням, дополнительные отверстия прямоугольной формы. По наличию дополнительных выступов выделяются два варианта:

A - с дополнительными выступами по краям, L1 = 12-15 мм, L2 = 22-50 мм;

Б - без дополнительных выступов по краям, L1 = 15-21 мм, L2 = 350-35 мм.

Пряжки без шпенька (около 50 экз.) по внешней форме и размерам ременных отверстий делятся на пять типов (Рисунок 23):

І тип - пряжки с круглым основным отверстием, без дополнительного отверстия для крепежного ремня, две стороны кольца выполнены в виде головок хищного животного, а промежуток между ними служил для крепления ремня, L1 $=10 \mathrm{Mm}, \mathrm{L} 2=22 \mathrm{MM}$.

II тип - пряжки с круглым основным отверстием, дополнительное отверстие для крепежного ремня нескольких вариантов:

A - дополнительное отверстие в виде петли, прикрепленной внутри небольшой полусферической бляшки, L1 = 10-20 мм, L2 = 30-32 мм;

Б - дополнительное отверстие для крепления ремня подпрямоугольной формы без дополнительных боковых выступов. В некоторых случаях бока украшены звериными рельефрными головками, L1 = 11-18 мм, L2 = 27-41 мм;

B - дополнительное отверстие для крепления ремня подтреугольной формы, L1 = 15-18 мм, L2 = 27-28 мм.

III тип - пряжки с овальным основным отверстием, дополнительное отверстие для крепежного ремня двух фрорм:

A - подпрямоугольной формы с дополнительными выступами для удержания ремня в определенном положении, L1 = 15-20 мм, L2 = 10-33 мм;

Б - трапециевидной формы без дополнительных выступов для удержания ремня в определенном положении, L1 = 21 мм, L2 = 28 мм.

IV тип - пряжки с сердцевидным отверстием, прямоугольным отверстием для крепежного ремня и дополнительными выступами для удержания его в определенном положении, L1 = 14-17 мм, L2 = 26-42 мм.

$\mathrm{V}$ тип - пряжки в виде ажурной спирали, ширина ременного отверстия достигает 42 мм.

Следующим элементом конского снаряжения являются седельные подушки и попоны. Об их существовании свидетельствуют, во-первых, нахождение подпружных пряжек, и, во-вторых, достаточно многочисленные изображения на ассирийских рельефрах VIII-VII вв. до н.э. Седла-попоны крепятся на спине лошади подпругой, а также нагрудным (подперсье) и в некоторых случаях подхвостным (потфейным) ремнями (Anderson 1961, pl. 6,11). Несколько позже, В VI-V вв. до н.э. кожаные подушки укрепляются планками (деревянными, костяными), чем создается определенная жесткость конструкции (Грязнов 1941, С.75 и сл.). К сожалению, для раннего периода археологические памятники не дают возможности реконструировать седельные комплексы достаточно полно. Они сохранились и прекрасно восстановлены для более позднего времени благодаря мерзлотным условиям Алтая (курганы пазырыкской эпохи), и поэтому для ранних периодов можно лишь моделировать их конструкцию с учетом поздних вариантов.

Итак, все элементы, составляющие комплект конского снаряжения, группируются по типам и вариантам, что позволяет провести их корреляционный анализ. Вначале необходимо выяснить, какие типы удил и псалиев сочетаются в одном комплекте. 
Материал поселений в этом отношении помочь не может, так как там если и находят какие-то элементы конского снаряжения (псалии, бляшки и т.д.), то либо во фррагментарном состоянии, либо другим материалом, не связанным с конским снаряжением. Другие археологические источники - случайные находки, клады и погребальные памятники, для рассматриваемого периода (начало 1 тыс. до н.э.) позволяют учесть более 100 комплектов из различных комплексов, значительная часть которых происходит из Аржан 1а-1 (86 комплектов). Это следующие сочетания:

1. Аржан 1: мягкие удила сочетаются с псалиями типа Па - 2 комплекта, удила IД7 с псалиями в виде кабаньих клыков - 2 компл., удила II-37 с деревянными псалиями и из клыков - по 1 компл., удила II-Ж7 с деревянными - 2 компл., удила III-И7 с деревянными - 8 компл., с псалиями из клыков - 1 компл., с псалиями типа Ila - 2 комлл., типа ІІв - 5 компл., типа IIIв - 33 компл., удила типа III-К7 coчетаются с деревянными - 3 компл., с псалиями типа ІІв - 1 компл. типа IIIв - 1 компл., удила IV-Л3 сочетаются с деревянными псалиями - 1 компл., удила IVЛ6 с деревянными - 1 комдл., удила вида IV-Л7 - с псалиями типа IIIв - 1 компл., удила вида Vб с деревянными псалиями - 5 компл., из клыков - 5 компл., с псалиями типа IIв - 1 компл., типа IIIв - 1 компл., удила вида Vla c псалиями из клыков - 2 компл., удила типа VIб с псалиями из клыков - 1 компл., с деревянными псалиями - 1 компл., типа ІІв - 6 компл., а типа IIІв - 1 компл.

2. Баданка IV. К. 17; мягкие удила сочетаются с псалиями из кабаньих клыков.

3. Курту II, к.3: мягкие удила сочетаются с псалиями типа IIIв.

4. Майэмир; удила типа III-К7 с деревянными псалиями.

5. Семисарт-1, кург.1: мягкие удила с псалиями IIб.

6. Коксу 1, кург.42: удила типа III-И7 с псалиями IV типа.

7. Усть-Куюм: мягкие удила сочетаются с псалиями типа ІІв.

8. Черный Ануй: удила типа III-И7 сочетаются с псалиями типа IIIб.

9. Суртайка: удила типа П-Ж7 с псалиями $\mathrm{V}$ типа.

10. Солонечный Белок, кург.2; удила типа III-K7 с псалиями типа V,

11. Алды-Бель, кург.21; удила типа II-37 с псалиями типа V.

12. Хемчик-Бом III, кург.1: удила типа II-36 с псалиями типа V.

13. Ортаа-Хем, кург. II; удила типа III-И7 с псалиями типа V.

14. Штабка: удила типа II-Ж7 с псалиями типа зооморфных наверший.

15. Гилево 10, мог.16.: удила типа II37-И7 с псалиями типа V.

16. Гилево 10, мог.31: удила типа III-И3 с псалиями типа Ila.

17. Гилево 10, мог.32: удила типа III-И7 с псалиями типа V.

18. Вакулиха 1, к.1: удила типа IV-И7 с псалиями типа IV.

19. Вакулиха 1, к.2: удила типа III-И7 с псалиями типа V.

20. Вакулиха 1, к.3: удила типа III-И7 с псалиями типа V.

21. Вакулиха 1, к.4: удила типа III-P6 с псалиями типа V.

22. Чекановский Лог-10: удила типа III-K7 с псалиями типа IIa.

23. Березовка: удила типа III-И7 с псалиями типа V.

24. Мельничная Гора: удила типа III-И6 с псалиями типа V.

25. Кондратьевка 21: удила типа II- 36 с псалиями типа V.

26. Камышинка : удила типа III-K7 с псалиями типа IIIб.

27. Герасимовка : удила типа III-K7 с псалиями типа IV.

28. Измайловка, о.17: удила типа III-K7 с псалиями типа VI.

29. Измайловка, о.17: удила типа IV-Л3 с псалиями типа VI.

30. Машенька 1 : удила типа III-K7 с псалиями типа V.

31. Покровский Лог-4, кург. 5: удила ременные с псалиями типа Ila.

32. Чесноково-1, кург.2: мягкие удила с псалиями типа Ila. 
33. Ак-Алаха-2: удила типа III-И7 с псалиями типа III.

34. Карбан-1, сев.: удила типа III-И5 с псалиями типа III.

35. Карбан-1, южн.: удила типа III-И7 с псалиями типа IIб.

36. Элекмонар-23, кург.1: удила типа II-37 с псалиями типа IIa.

37. Бийке, кург.17: удила мягкие с псалиями типа Ila.

38. Черный Ануй-1: удила типа III-И7 с псалиями типа IIIв.

40. Кор-коба-1, кург.24: мягкие удила с псалиями типа Ila.

41. Бойтыгем-2, кург.2: удила типа III-E7 с псалиями типа IV.

42. Каракол, кург.1: удила типа II-37 с псалиями типа V.

43. Кок-су, кург.42: удила типа III-И7 с псалиями типа IV.

44. Аржан 2: удила типа IV-M7 с псалиями типа IV.

Наиболее многочисленное сочетание, распространенное в Центральной Азии, удил типа III-И7 с псалиями типа IIB, IIIB, а также из органического материала (дерева, кожи). В меньшей степени употреблялись комплекты, состоящие из удил типа Vб - псалиев из клыков, либо деревянных, и удил типа VIб и псалиев типа ІІв. Остальные комплекты пока фриксируются в небольших количествах. Такой значительный закрытый комплекс, как Аржан 1, содержит, например, удила 7 типов (12 вариантов) и псалии 5 типов (6 вариантов), что составляет 24 разнотипных комплекса конских уздечек, существовавших одновременно. Всего для Центральной Азии по имеющимся материалам можно зафриксировать около 35 различных вариантов IX-VI вв. до н.э. Такое сравнение еще раз наглядно показывает, что комплексы Аржан 1а, во-первых, действительно составляют совокупность различных территориальных и культурных подразделений и, во-вторых, свидетельствуют о неравномерности исторического развития, о разном уровне технической оснащенности. В частности, прекрасным примером служит сочетание в одном комплексе архаичных деревянных или примитивных, выполненных из челюсти лошади, псалиев и искусно выполненных из бронзы псалиев и однокольчатых удил, которые, как уже отмечалось, найденные порознь, датировались бы от X до V вв. до н.э. (Боковенко 1979, С.70).

Остальные элементы конской сбруи в значительной мере дополняют представления о комплектах, но достаточно четкой корреляции с какими-то типичными наборами проследить не удается, хотя в некоторых случаях улавливаются определенные тенденции в типологическом развитии некоторых деталей (перекрестников ремней, подпружных пряжек, затылочных обойм). К примеру, составляются такие комплекты узды Коксу 1, к.42 включают: ППш IVa, ППб Па, ОПР ШШ; Камышинка - ППш Шб, ППб Пб, ОПР IVБ, ОПР IVA; Хемчик-Бом III, к.1,2 ППш IIIA, ППб 1, НЩБ V и т.д. Типологический анализ конского снаряжения Аржан 1а позволяет выявить регионы, где представлены предшествующие аржанским фрормам и откуда они могли попасть в курган в качестве даров. Это прежде всего нагрудное украшение в виде кошачьего хищника из Монголии, миниатюрные однокольчатые удила из Минусинской котловины, роговые трехдырчатые псалии куртусского типа, аналогичные алтайским и украшенные по стержню квадратиками удила, характерные для Казахстана. Отсутствие источников и неразработанность хронологии не позволяют более конкретно решить вопросы культурогенеза Аржан 1а. В целом намечаются тенденции развития основных элементов конской сбруи и при достаточно надежной хронологической привязке, наличие определенных типов и их сочетаний, в свою очередь, будет служить своеобразным хронологическим индикатором для остальных компонентов погребального инвентаря. Так, внутренний диаметр однокольчатых удил менялся во времени. Наиболее ранние удила (тип VA, Б), относящиеся к самому началу 1 
тыс. до н.э., имитирующие ременные, имели небольшие отверстия до 20 мм в диаметре (Аржан 1), у более поздних удил (тип VB) внутренний диаметр 21-34 мм (Туэкта, Пазырык и др.). Аналогичная ситуация прослеживается при анализе размеров элепсовидных окончаний удил (тип VI). Соотношение наименьшего размера 10-17 мм к наибольшему 17-21 мм (типы VI A, Б) наиболее характерно для удил Аржан 1a, а соотношение наименьшего размера 25 мм к наибольшему 36 мм (тип VI B) представлено в удилах из курганов Алтая (Пазырык II).

Между Аржан 1 и Пазырыком (к.2) по данным дендрохронологии - около 550 лет (Марсадолов 1985, С.10). Следовательно, напрашивается вывод, что удила с соотношениями большого и малого размеров внутренних отверстий удил, помещающиеся на графике (Рисунок 2) между Аржан 1 и Пазырыком II, могут быть также датированы в этом промежутке. Чем больше будет опорных памятников, тем точнее можно будет продатировать одиночные находки удил по количественным критериям. Но все же необходимо учитывать, что эта схема не абсолютна, а выявляет тенденции изменения количественных параметров удил и исключения возможны.

Количественные критерии частично являются диагностическими признаками при рассмотрении подпружных пряжек. Измерялись размеры отверстий для продевания крепежного ремня и подпружного, что сразу позволило выявить из этой категории блоки повода для чумбура. У подпружных пряжек Аржан 1 крепежное и подпружное отверстие одно и тоже (ширина 20 мм), в VII в. до н.э. уже появляется либо шпенек, либо отверстие (до 20 мм) для крепежа к седельной попоне подпружной пряжки (Кок-су 1, к.42) (Сорокин 1974). Подпружное отверстие уже достигает 51 мм. Материалы VI в. до н.э, показывают увеличение до 33 мм и более подпружного отверстия и увеличение массивности самой прядки (Туэкта, Башадар, Пазырык), что скорее всего связано с усложнением конструкции седла от простой попоны до седла на мягкой основе, но с деревянным примитивным каркасом.

До и для этой категории нет достаточно четкой закономерности развития, а прослеживаются лишь некоторые тенденции изменения пропорций пряжек.

Налобные бляхи сначала предоставлены круглыми золотыми кольцами со серебряными круглыми вставками (Аржан 1), затем изменились их пропорции, они типологически развились и стали (более рельефными (Пазырык). Соответствующим образом изменилась и остальные элементы узды.

К сожалению, конкретное развитие того или иного типа узды удается проследить не всегда. Это связано не только с отсутствием материалов по этому аспекту, до и сложностями в хронологии археологических памятников Центральной Азии. Особая ситуация складывается на Среднем Енисее, где конское снаряжение представлено практически полностью случайными находками

Чрезвычайно многочисленны предметы конского снаряжения (удила, псалии, пряжки) великолепного качества по исполнению, что свидетельствует о высокой значимости этой категории для тагарского общества. Обилие и разнообразие предметов конского убора, многочисленные наскальные изображения достаточно убедительно говорят о высокой значимости коневодства в тагарской культуре.

Этапы развития конского снаряжения (Рисунок 24). Древнейший этап (середина 2 тыс. - конец 2 тыс. до н.э.) по всей зоне евразийских степей представлен мягкими удилами из скрученных ремней и трехдырчатыми псалиями (тип 1) из органического материала (рог, кость, клык, дерево-кожа), а в очень редких случаях - из бронзы. Форма псалиев и отверстий варьирует в пределах естественных возможностей материала, имеет часто характерную для рога 
изогнутость и свидетельствует о несложившихся традициях в производстве псалиев (Ирмень, Устинкино, Еловка и др.). Существует два варианта расположения трех отверстий у псалиев: в разных плоскостях (более архаичный) и в одной плоскости (более поздний). Отверстия равномерно распределены по плоскости псалия. Немногочисленная орнаментация псалиев преимущественно геометрическая. Они очень широко распространяются по всей зоне степей. Остальные элементы конской сбруи с достаточно четко определенной функцией еще не выработались, их пока еще заменяли ременные узлы и сочленения. В это время, видимо, кони использовались в качестве упряжных, хотя не исключена возможность использовать их эпизодически под верховую езду (пастухами), но для суждений о массовом (историческом) явлении оседлании коня пока нет никаких археологических данных.

Начальный этап эпохи ранних кочевников (примерно IX-VII в. до н.э.) в конечной своей фазе обусловленный как повсеместным внедрением бронзы в наиболее функциональные части конской узды, так и значительным совершенствованием способов управления конем. У роговых (костяных) псалиев отверстия расположены в одной плоскости (тип II, отчасти III), позже они смещаются к центру. Вокруг отверстий намечаются утолщения (Курту II, Усть-Куюм) (Сорокин 1969), начинают оформляться окончания псалиев, выполненные из бронзы; они имитируют роговые; типологические рудименты последних широко представлены. Эти типы псалиев также достаточно широко распространяются по евразийским степям (Смирнов 1961, С.66).

Аналогичная ситуация наблюдается и среди бронзовых удил, которые первоначально копируют ременные (типа 1А, УА, VIA, VII). На конечной фазе этого этапа окончание двукольчатых удил значительно варьирует по форме (типы 1IV уровня 3-6), дополнительное небольшое отверстие постепенно вписывается в общую конфигурацию окончаний удил. Видимо, для этого времени характерно применение наряду с существующими псалиями, генетически связанными с псалиями эпохи бронзы (тип П) и псалиев новых форм, например, строгих («скребниц»).

Отражением складывающихся устойчивых традиций являются псалии с тремя отверстиями в одной плоскости, имитирующие характерную изогнутость роговых изделий. По ассирийским рельефам можно отчасти реконструировать систему кропления удил и псалиев, а также ремней узды. Так, для IX в.до н.э. характерна уздечка с оголовьем из широких ремней, покрытых бляшками: налобного, затылочного, подганашного, закрепленного наглухо с помощью двух овальных или прямоугольных перекрестных блях и дополнительного затылочного - подганашного ремня, который закреплялся после надевания уздечки (An-derson 1961, pl. 3,4; Ковалевская 1977, С.81 и сл.). Спецификой уздечки IX в. до н.э. было отсутствие наносного ремня. Обычно грудь коня защищалась кожаным нагрудником с висящими кистями, который соединялся с передней подпругой у колесничного коня и о седлом-попоной у верхового. Начельник у верховой лошади обычно отсутствовал, а у колесничной имел форму полукружия. Судя по первым изображениям всадника, В.Б. Ковалевская приходит к выводу, что в то время у верховой узды сохраняется много элементов упряжной, видимо, еще не совсем отошли от принципов узды на колеснице.

IX-VIII вв. до н.э. также характеризуются значительным разнообразием типов удил и псалиев. Если в форме удил прослеживается стремление упростить их (исчезает маленькое дополнительное отверстие - уровень 7), то новый материал Отражением складывающихся устойчивых традиций являются псалии с тремя отверстиями в одной плоскости, имитирующие характерную изогнутость 
роговых изделий. По ассирийским рельефам можно отчасти реконструировать систему кропления удил и псалиев, а также ремней узды. Так, для IX в.до н.э. характерна уздечка с оголовьем из широких ремней, покрытых бляшками: налобного, затылочного, подганашного, закрепленного наглухо с помощью двух овальных или прямоугольных перекрестных блях и дополнительного затылочного - подганашного ремня, который закреплялся после надевания уздечки (Anderson 1961, pl. 3,4; Ковалевская 1977, С.81 и сл.). Специфрикой уздечки IX в. до н.э. было отсутствие наносного ремня. Обычно грудь коня защищалась кожаным нагрудником с висящими кистями, который соединялся с передней подпругой у колесничного коня и о седлом-попоной у верхового. Начельник у верховой лошади обычно отсутствовал, а у колесничной имел форму полукружия. Судя по первым изображениям всадника, В.Б. Ковалевская приходит к
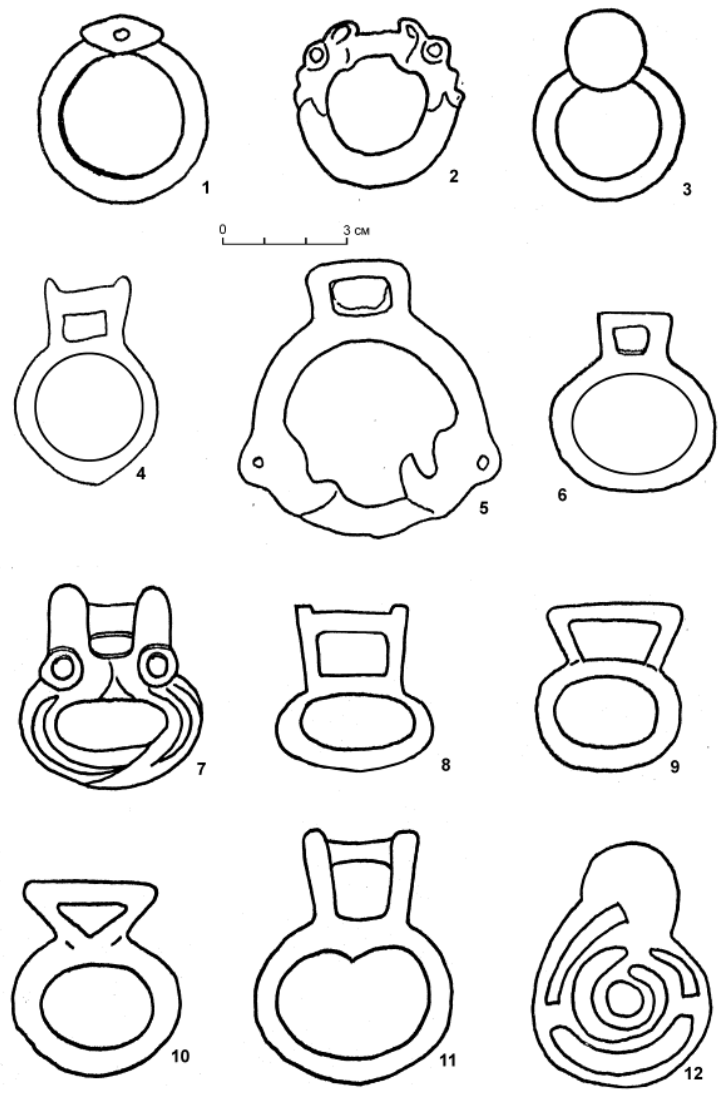

Рисунок 24. Комплекты узды Саяно-Алтая IX-VII вв. до н.э.: I - комплекты Аржана, 2 - комплекты из остальных комплексов. Развитие одного из комплектов узды Саяно-Алтая: I - древнейший (реконструкция по фригурной головке из кургана Аржан), II - Аржан, III - Пазырык (по М.П. Грязнову) выводу, что в то время у верховой узды сохраняется много элементов упряжной, видимо, еще не совсем отошли от принципов узды на колеснице.

Бронза позволяет создать принципиально новые типы псалиев («V»-образные - V тип, с уступом - IV тип, VII тип). Однако подобное усложнение этой важной функциональной категории, появившееся, скорее всего благодаря естественным возможностям нового материала, оказалось в дальнейшем нежизненным. Для этого этапа характерны разнообразные комплекты удил и псалиев. Интенсивно разрабатываются и совершенствуются остальные элементы узды (различные типы обойм для перекрестия ремней, нащечные бляхи, затылочные обоймы, украшения для ремней, подпружные пряжки и т.д.) Причем, кроме чисто практического значения, эти дополнительные элементы несут и эстетическую нагрузку, так как на некоторых появляются детали звериного стиля, орнаментальные мотивы, знаковая символика.

B IX-VIII в. до н.э. кожаные нагрудники продолжают использовать, аржанские иногда украшены (а вернее, усилены) клыками животных. Грудь одного из аржанских коней украшала великолепная бронзовая бляха в виде свернувшегося кошачьего хищника (Грязнов 1980, С.28, рис.15,4). Скульптурное изображение головы коня из рога наглядно показывает способ соединения ремней оголовья, что может еще раз свидетельствовать в пользу ранней даты Аржан 1а, так как здесь отсутствует наносный ремень, а его заменяют ремни, идущие к кожаному налобнику (Грязнов 1980, С.28, рис.15,1-3). 
Судя по ассирийским рельефам, изменяется и снаряжение передневосточных всадников: появляются на ошейнике кисти-науза, через которые проходил ремень поводьев.

Этим достигалось фиксирование положения повода на голове коня. Всадник освобождался от угрозы потерять при движении повод (Ковалевская 1977, C.84). Появляется прямой наносный, начельник, исчезает один из налобноподганашных ремней. В Ассирии распространяются прямоугольные пластинчатые псалии, а также изогнутые роговые псалии (II тип), что считают влиянием скифов и мидийцев. И действительно, для начала 1 тыс. до н.э. в северных степных регионах от Венгрии до Тувы в целой серии памятников зафиксированы подобные псалии (Субботово, Сахарна, Царевка, Черногоровка, Кобанский могильник, Курту II, Аржан 1 и др.) (Тереножкин 1976). Бронзовые удила преобладают повсеместно, кость (рог) используется в меньшей степени и часто при изготовлении второстепенных элементов сбруи. На поселении Кент (Казахстан) конца эпохи бронзы зафиксирована отливка одного из звена удил со стремявидным окончанием (Вафоломеев, 1987), что указывает на возможный регион их происхождения. Именно с начала I тыс. до н.э. наблюдается наибольшая вариация бронзовых удил и псалиев за весь период кочевничества. Модификация конского снаряжения сочетается с локализацией отдельных удил и псалиев. Так, например, двукольчатые удила с равновеликими отверстиями, имеющие на конце подвижные части (псалии VII типа), распространяются очень широко по всей зоне степей, но в основном преобладают в Северном Причерноморье (Высокая Могила, Зольное, Новочеркасский клад, Бутенки, Пятигорск и др.) и частично в Поволжье (биляр), лишь единичные находки известны в Южной Сибири и Центральной Азии (Минусинский край - АМ ТГУ № 4567). Удила с так называемыми стремечковидными окончаниями чрезвычайно разнообразны в восточной части степей (типы 1-IV), это позволяет в достаточной степени уверенно еще раз утверждать, что они азиатского происхождения, как полагал А.А. Иессен (1954, Р.129), а затем В.А. Грач (1975). Простые стремечковидные удила (типы 17, П7, Ш7, IV7) очень широко бытовали по всей зоне степей Евразии, правда, в Северном Причерноморье и на Кавказе представлены экземпляры в техническом отношении исполненные менее совершенно. Типы удил 1Б, В, Г, Д; ПЕ известны только в Минусинском крае, типы ПЖ, 3, ШИ,К, УА,Б, УХА,Б распространены значительно шире: в Казахстане (Тасмола, Тагискен, Семипалатинск, Толагай и др.), в майэмирских памятниках Алтая, в минусинских степях.

Форма псалиев этого типа тоже весьма варьирует, но основная конструктивная особенность - трехдырчатость остается неизменной. Для наиболее ранних комплексов, в особенности для восточного региона степей, характерно сочетание бронзовых удил и роговых псалиев (Аржан 1, Тагискен, Уйгарак). Комплекты стремечковидных удил и псалиев П типа (с грибообразными окончаниями) встречаются от Северного Причерноморья (Камышеваха) до Тувы (Аржан 1), сочетание удил - типа П3, IVЛ, с V-образными псалиями (V тип) распространено на значительно меньшей территории (Казахстан, Алтай, Тува), а комплект из удил с уступом с стержневидных удил с уступом и стержневидных трехдырчатых псалиев (среднее отверстие выполнено в виде петли) пока известно только в Казахстане. Локальные специфические комплекты известны и для других мест. Появление многочисленных пряжек, бляшек, разъединителей ремней вполне отражает тенденцию постоянного совершенствования раннескифской сбруи. Распространяется обычай подвязывать хвосты, либо перевязывать их у репицы и посередине (нахвостники Аржан 1а). 
На ассирийских изображениях VIII века до н.э. всадники сидят на небольших седлах-попонах (с острыми углами и кистями по краю), закрепленные при помощи передних подпруг и нагрудных ремней (Anderson 1961, pl. 4a, 5a). Видимо, аналогичные попоны коврового типа были и в Аржан 1е (найдены остатки ковров и подпружные пряжки типа ППш1). Подпружные пряжки поздних типов (II, III, IVA) найдены в других памятниках Тувы (Алды-Бель 1, Хемчик-Бом III, Ортаа-Хем) и Алтая (Коксу 1 и др.). В дальнейшем эти попоны-седла получили типологическое развитие на Алтае (Пазырык), где обнаружены кожаные подушки, набитые волосом, с низкими деревянными луками (Грязнов, 1950, с.57). C VI-У века до н.э. начинается качественно новый этап, характеризующийся повсеместным распространением однокольчатых удил (типы УВ, VIB) и двудырчатых псалиев, которые в конце концов вытесняют остальные типы удил и псалиев, внедряется новый материал - железо, вводятся элементы украшательства. Псалии вставляются в расширенные отверстия удил. Эти существенные изменения конской сбруи, видимо, создали новые возможности управления конем; они были весьма значительными и охватили все евразийские степи. Стремечковидные типы удил уже не изготовлялись, хотя кольчатые из бронзы в незначительном количестве продолжают существовать. Окончания псалиев моделированы в виде головок различных животных, франтастических зверей, грифонов (Туэкта, Пазырык и др.) и чаще всего выполнены из дерева, а в наиболее богатых могилах обложены листовым золотом или посеребрены. Аналогичное офрормление имеется на ремнях оголовья. Новые моменты наблюдаются в орнаментальных мотивах, типологически вырастающих из «звериного стиля». В могильнике Берел обнаружена уникальная узда, которая полностью украшена костяными фигурными пряжками (Самашев 2011, рис.416422). Подобное введение элементов украшательства на строго функциональных частях сбруи свидетельствовало, во-первых, о принадлежности погребенного к определенному социальному слою, подчеркивало его высокое (почетное) положение в обществе, во-вторых, о возросшей роли эстетического фактора. Возможны и другие аспекты идеологического плана. Типологически развиваются ременные и подпружные пряжки (типы 3Р1 П; Пш ПБ В; IVB Г; НЩБ III,IV; 30 П-IV; РД IV). Подробный анализ конского снаряжения этого пазырыкского периода не входит в тему данного исследования.

Вся совокупность исследованного материала Центральной Азии показала, что этому региону в сложении культуры ранних кочевников принадлежит ведущее место, о чем убедительно свидетельствуют материалы царского кургана Аржан 1 в Туве, где захоронен вождь конфедерации многих племен. Начальный этап или Аржан1-черногоровскую фразу (по М.П. Грязнову) развития культур скифского типа скорее всего можно датировать IX-VII вв. до н.э. Эту дату подтверждает не только типологический анализ конского снаряжения (Боковенко 1979; Грязнов 1981; Медведская 1983), погребального обряда (Боковенко 1979, 1981, 1986; Марсадолов 1985; Степанова 1986), произведений изобразительного искусства Саяно-Алтая (Шер 1980; Дэвлет, 1984 и др.), но также данные письменных источников. Во-первых, наиболее ранние античные свидетельства о скифах и киммерийцах сейчас относят к азиатским регионам (Ельницкий 1977; Куклина 1985). Во-вторых, переднеазиатские письменные источники убедительно свидетельствуют о появлении там с севера и северо-востока предположительно в IX-VIII вв. до н.э. (Иессен 1954) и наиболее достоверно в VIII в. до н.э. (Дьяконов 1956; Грантовский 1970 и др.) вооруженных групп всадников, двигавшихся с востока на запад (Дьяконов, 1956, С.237). В это же время они фриксируются на границах Урарту (Пиотровский 1949а, С.172). В данном 
случае не важно, что это были за племена (киммерийцы, скифы, саки или другие этнические группы), но принципиальное значение имеет их всаднический облик, военная оснащенность организованность и способность противостоять военным формированиям переднеазиатских государств уже в VIII в. до н.э. Следовательно, можно предполагать, что процесс их консолидации как мобильной мощной исторической силы Центральной Азии охватывает, как минимум IX в. до н.э., а, возможно, и раньше.

\section{Әдебиеттер тізімі/ Список литературы}

1. Акишев К.А. Саки азиатские и скифы европейские (общее и особенное в культуре) // Археологические исследования в Казахстане. - Алма-Ата, 1973. - С.43-58.

2. Акишев К.А., Акишев А.К. Проблема хронологии раннего этапа сакской культуры // Археологические памятники Казахстана. - Алма-Ата, 1978. - С.58-64.

3. Барминцев Ю.Н. Эволюция конских пород в Казахстане. - Алма-Ата, 1958. - 284 с.

4. Боковенко Н.А. 2010. Начало тагарской эпохи // Древние культуры Евразии. - СПб. - С.99-103.

5. Боковенко Н.А. Ранние формы скифо-сибирокой узды // ТД ВК Проблемы скифо-сибирского культурно-исторического единства. - Кемерово, 1979. - С.67-70.

6. Боковенко Н.А. Динамика развития конской сбруи в скифское время на Алтае (к проблеме цикличности инноваций) // Преемственность и инновации в развитии древних культур. - Л., 1981. - С.55-57.

7. Боковенко Н.А. 1986. Начальный этап культуры ранних кочевников Саяно-Алтая (по материалам конского снаряжения): Автореф. дис.: канд. ист. наук. - Л., 1986. - 24 с.

8. Витт В.0. Лошади Пазырыкских курганов // Советская археология. - 1952. - №16. - С.185-224.

9. Вишневская О.А. Культура сакских племен низовьев Сырдарьи в УП-У1 вв. до н.э. - М., 1975. - 160 с.

10. Грантовский Э.А. Ранняя история Иранских племен Передней Азии. - М., 1970. - 595с.

11. Грач А.Д. Древние кочевники в центре Азии. - М., 1980. - 256 с.

12. Грач В.А. Бронзовые удила скифского времени (вопросы происхождения. Хронологии и распространение) // 11-я ИСК. - Новосибирск, 1975. - С.54-56.

13. Гришин Ю.С. Производство в тагарскую эпоху // Материалы и исследования по археологии. 1960. - №90. - 206 с.

14. Грязнов М.П. Первый Пазырыкский курган. - Л., 1950. - 81 с.

15. Грязнов М.П. Пазырык. Погребение племенного вождя на Алтае: Дисс. докт.ист.наук. - Л., 1941. -593 c.

16. Грязнов М.П. Памятники майэмирского этапа эпохи ранних кочевников на Алтае // Краткие сообщения института истории материальной культуры. - 1947. - Вып.18. - С.9-17.

17. Грязнов М.П. Аржан - царский курган раннескифского времени. - Л., 1980. - 63 с

18. Грязнов М.П. Начальная фаза развития скифо-сибирских культур // Археология Южной Сибири. - Кемерово, 1983. - С.5-18.

19. Дьяконов И.М. История Мидии. - М.-Л., 1956. - 485 с.

20. Дэвлет М.А. Петроглифы скифо-сибирского звериного стиля в Саянском каньоне Енисея // Скифо-сибирокий мир. - Кемерово, 1984. - С.25-24.

21. Ельницкий Л.А. Скифия евразийских степей. - Новосибирск, 1977. - 256 с.

22. Ермолаева А.С. Памятники предгорной зоны Казахского Алтая (эпоха бронзы-раннего железа). - Алматы, 2012. - 213 с.

23. Иессен А.А. Некоторые памятники VIII-VII вв. до н.э. на Северном Кавказе // Вопросы скифосарматской археологии. - М., 1954. - С.112-131.

24. Кадырбаев М.К. Памятники тасмолинской культуры // Древняя культура Центрального Казахстана. - Алма-Ата, 1966. - С.303-455.

25. Кадырбаев М.К. Некоторые итоги и перспективы изучения археологии раннежелезного века Казахстана // Новое в археологии Казахстана. - Алма-Ата, 1968. - С.24-51.

26. Кадырбаев М.К. Скотоводство (историко-археологический очерк) // Хозяйство казахов на рубеже X1X-XX веков. - Алма-Ата, 1980.

27. Карлсен Г.Г. Тренинг и испытание рысаков. - М., 1978. - 255 с.

28. Кирюшин Ю.Ф., Тишкин А.А. Скифская эпоха Горного Алтая. - Ч.1. - Барнаул, 1997. - 232 с.

29. Киселев С.В. Древняя история Южной Сибири. - М., 1951. - 645 с.

30. Ковалевская В.Б. Конь и всадник. - М., 1977. - 152 с.

31. Куклина И.В. Этногеография Скифии по античным источникам. - Л., 1985. - 206 с.

32. Майдар М. Памятники истории и культуры Монголии. - М., 1981. - 74 с. 
33. Маргулан А.Х., Акишев К.А., Кадырбаев М.К., Оразбаев А.М. Древняя культура Центрального Казахстана. - Алма-Ата, 1966. - 455 с.

34. Марсадолов Л.С. Хронология курганов Алтая (VIII-IV вв. до н.э.): Автореф. дис. : канд. ист. наук. - Л., 1985. - 16 с.

35. Пиотровский Б.Б. Скифы в Закавказье // Ученые записки ЛГУ. - 1949. - Вып.15 (85). - С.172-189.

36. Руденко С.И. Культура населения Горного Алтая в скифское время. - М.-Л., 1953. - 402 с.

37. Руденко С.И. Культура населения Центрального Алтая в скифское время. - М.-Л., 1960. - 359 с.

38. Руденко С.И. К вопросу о формах сктоводческого хозяйства и о кочевниках // Материалы по этнографии. Выпуск 1. Географическое общество Союза ССР. - Ленинград, 1961. - С. 2-15.

39. Самашев 3. Берел. - Алматы, 2011. - 236 с.

40. Смирнов К.Ф. Савроматы. - М., 1964. - 579 с.

41. Сорокин С.С. Памятники ранних кочевников в верховьях Бухтармы // Археологический сборник Государственного Эрмитажа. - 1966. - Вып. 8.

42. Сорокин С.С. Новый памятник VII-VI вв. до н.э. на Южном Алтае // Советская археология. 1969. - №2. - C.249-252.

43. Сорокин С.С. Цепочка курганов времени ранних кочевников на правом берегу Кок-Су (Южный Алтай) // Археологический сборник государственного эрмитажа. - Вып.16. - Л., 1974. - С.62-91. 44. Степанова Н.Ф. Куюмский тип памятников VIII-VI вв. до н.э. // Скифская эпоха Алтая: Тезисы докладов к конференции. - Барнаул, 1986. - С. 79-81.

45. Тереножкин А.И. Киммерийцы. - Киев, 1976. - 223 с.

46. Урусов С.П. Книга о лошади. - Т.1, 2. - СПб, 1911.

47. Членова Н.Л. Происхождение и ранняя история племен тагарской культуры. - М., 1967. - 298 с. 48. Шер Я.А. Петроглифы Средней и Центральной Азии. - М., 1980. - 328 с.

49. Шульга П.И. Снаряжение верховой лошади и воинские пояса на Алтае. Ч. І: Раннескифское время / Ред. Ю.Ф. Кирюшин, А.А. Тишкин. - Барнаул: Азбука, 2008. - 276 с.

50. Anderson J.K. Ancient Greek Horsemanship. - Berkeley-Los Angeles, 1961. - 329 p.

51. Schmidt E. Persepolis: V.1-2. - Chicago, 1957. - 297 p.

52. Tallgren A.M. Collestion Tovostine. - Helsinki, 1917. - 93 p.

\section{Reference}

Akishev 1973 - Akishev, KA 1973, Saki aziatskie i skify evropejskie (obshchee i osobennoe v kul'ture), Arheologicheskie issledovaniya v Kazahstane, Alma-Ata, S.43-58. (Akishev, KA 1973, Saki Asian and Scythians European (general and special in culture), Archaeological research in Kazakhstan, Alma-Ata, P.43-58). (in Rus).

Akishev, Akishev 1978 - Akishev, KA, Akishev, AK 1978, Problema hronologii rannego ehtapa sakskoj kul'tury, Arheologicheskie pamyatniki Kazahstana, Alma-Ata, S.58-64. (Akishev, KA, Akishev, AK 1978, The problem of chronology of the early Saka culture, Archaeological monuments of Kazakhstan, Alma-Ata, P.58-64). (in Rus).

Anderson 1961 - Anderson, JK 1961, Ancient Greek Horsemanship, Berkeley-Los Angeles, 329 p. (Anderson, JK 1961, Ancient Greek Horsemanship, Berkeley-Los Angeles, 329 p). (in Rus).

Barmincev 1958 - Barmincev, YuN, 1958, EHvolyuciya konskih porod v Kazahstane, Alma-Ata, $284 \mathrm{~s}$. (Barmincev, YuN, 1958, Evolution of horse breeds in Kazakhstan, Alma-Ata, 284 p). (in Rus).

Bokovenko 1981 - Bokovenko, NA 1981, Dinamika razvitiya konskoj sbrui v skifskoe vremya na Altae (k probleme ciklichnosti innovacij), Preemstvennost' $i$ innovacii $v$ razvitii drevnih kul'tur, Leningrad, S.55-57. (Bokovenko, NA 1981, Dynamics of the development of horse harness in the Scythian time in the Altai (to the problem of cyclicity of innovations), Continuity and innovation in the development of ancient cultures, Leningrad, P.55-57). (in Rus).

Bokovenko 1986 - Bokovenko, NA 1986, Nachal'nyj ehtap kul'tury rannih kochevnikov Sayano-Altaya (po materialam konskogo snaryazheniya): Avtoref. dis.: kand. ist. Nauk, Leningrad, 24 s. (Bokovenko, NA 1986, The initial stage of the culture of the early nomads of the Sayano-Altai (based on equestrian equipment): The author's abstract of the dissertation: the candidate of historical sciences, Nauka, Leningrad, 24 p). (in Rus).

Bokovenko 2010 (1) - Bokovenko, NA 2010, Nachalo tagarskoj ehpohi, Drevnie kul'tury Evrazii, SanktPeterburg, S.99-103. (Bokovenko, NA 2010, Beginning of the Tagar era, Ancient cultures of Eurasia, St. Petersburg, P.99-103). (in Rus).

Bokovenko 2010 (2) - Bokovenko, NA 2010, Rannie formy skifo-sibirokoj uzdy, TD VK Problemy skifosibirskogo kul'turno-istoricheskogo edinstva, Kemerovo, S.67-70. (Bokovenko, NA 2010, Early forms of the Scythian-Siberian relic, TD VK Problems of the Scythian-Siberian cultural and historical unity, Kemerovo, P.67-70). (in Rus). 
CHlenova 1980 - Chlenova, NL 1980, Proiskhozhdenie i rannyaya istoriya plemen tagarskoj kul'tury, 298 s. (Chlenova, NL 1980, The origin and early history of the tribes of Tagar culture, 298 p). (in Rus).

D'yakonov 1956 - D'yakonov, IM 1956, Istoriya Midii, Moskva-Leningrad, 485 s. (D'yakonov, IM 1956, The history of Midia, Moscow-Leningrad, 485 p). (in Rus).

Dehvlet 1984 - Dehvlet, MA 1984, Petroglify skifo-sibirskogo zverinogo stilya v Sayanskom kan'one Eniseya, Skifo-sibirokij mir, Kemerovo, S.25-24. (Dehvlet, MA 1984, Petroglyphs of the ScythianSiberian animal style in the Sayan canyon of the Yenisei, the Scythian-Siberian world, Kemerovo, P.25-24). (in Rus).

El'nickij 1977 - El'nickij, LA 1977, Skifiya evrazijskih stepej, Novosibirsk, 256 s. (El'nickij, LA 1977, Scythia of the Eurasian steppes, Novosibirsk, 256 p). (in Rus).

Ermolaeva 2012 - Ermolaeva, AS 2012, Pamyatniki predgornoj zony Kazahskogo Altaya (ehpoha bronzy-rannego zheleza), Almaty, $213 \mathrm{~s}$. (Ermolaeva, AS 2012, Monuments of the foothill zone of the Kazakh Altai (Bronze Age-Early Iron Age), Almaty, 213 p). (in Rus).

Grach 1975 - Grach, VA 1975, Bronzovye udila skifskogo vremeni (voprosy proiskhozhdeniya. Hronologii i rasprostranenie), 11-ya ISK, Novosibirsk, S.54-56. (Grach, VA 1975, Bronze bits of Scythian time (questions of origin.) Chronology and distribution), 11-ya ISK, Novosibirsk, P.54-56). (in Rus).

Grach 1980 - Grach, AD 1980, Drevnie kochevniki v centre Azii, Moskva, 256 s. (Grach, AD 1980, Ancient nomads in the center of Asia, Moscow, $256 \mathrm{p}$ ). (in Rus).

Grantovskij 1970 - Grantovskij, EHA 1970, Rannyaya istoriya Iranskih plemen Perednej Azii, Moskva, 595 s. (Grantovskij, EHA 1970, Early history of the Iranian tribes of the Near East, Moscow, 595 p). (in Rus).

Grishin1960 - Grishin, YuS 1960, Proizvodstvo v tagarskuyu ehpohu, Materialy $i$ issledovaniya po arheologii, № 90, 206 s. (Grishin, YuS 1960, Production in the Tagar era, Materials and research on archeology, № 90, 206 p). (in Rus).

Gryaznov 1950 - Gryaznov, MP 1950, Pervyj Pazyrykskij kurgan, Leningrad, 81 s. (Gryaznov, MP 1950, The first Pazyryk mound, Leningrad, 81 p). (in Rus).

Gryaznov 1941 - Gryaznov, MP 1941, Pazyryk. Pogrebenie plemennogo vozhdya na Altae: Diss. dokt.ist.nauk, Leningrad, 593 s. (Gryaznov, MP 1941, Pazyryk. Burial of the tribal leader in the Altai: Diss. doctor of historical sciences, Leningrad, 593 p). (in Rus).

Gryaznov 1947 - Gryaznov, MP 1947, Pamyatniki majehmirskogo ehtapa ehpohi rannih kochevnikov na Altae, Kratkie soobshcheniya instituta istorii material'noj kul'tury, Vyp.18, S. 9-17. (Gryaznov, MP 1947, Monuments of the Mayemir stage of the era of the early nomads in the Altai, Brief communications of the Institute of the History of Material Culture, Issue 18, P. 9-17). (in Rus).

Gryaznov 1980 - Gryaznov, MP 1980, Arzhan - carskij kurgan ranneskifskogo vremeni, Leningrad, 63 s. (Gryaznov, MP 1980, Arzhan - the royal barrow of the early Scythian time, Leningrad, 63 p).(Rus).

Gryaznov 1983 - Gryaznov, MP 1983, Nachal'naya faza razvitiya skifo-sibirskih kul'tur, Arheologiya YUzhnoj Sibiri. Kemerovo, S. 5-18. (Gryaznov, MP 1983, The initial phase of the development of Scythian-Siberian cultures, the archeology of Southern Siberia, Kemerovo, P. 5-18). (in Rus).

lessen1954 - lessen, AA 1954, Nekotorye pamyatniki VIII-VII vv. do n.eh. na Severnom Kavkaze, Voprosy skifo-sarmatskoj arheologii, Moskva, S.112-131. (lessen, AA 1954, Some monuments of VIII-VIII centuries. BC. in the North Caucasus, Questions of Scythian-Sarmatian archeology, Moscow, P.112-131). (in Rus).

Kadyrbaev 1966 - Kadyrbaev, MK 1966, Pamyatniki tasmolinskoj kul'tury, Drevnyaya kul'tura Central'nogo Kazahstana, Alma-Ata, S.303-455. (Kadyrbaev, MK 1966, Monuments of Tasmolin culture, Ancient culture of Central Kazakhstan, Alma-Ata, P.303-455). (in Rus).

Kadyrbaev 1968 - Kadyrbaev, MK 1968, Nekotorye itogi i perspektivy izucheniya arheologii rannezheleznogo veka Kazahstana, Novoe v arheologii Kazahstana, Alma-Ata, S.24-51. (Kadyrbaev, MK 1968 , Some results and prospects of studying the archeology of the Early Iron Age of Kazakhstan, New in Archeology of Kazakhstan, Alma-Ata, P.24-51). (in Rus).

Kadyrbaev 1980 - Kadyrbaev, MK 1980, Skotovodstvo (istoriko-arheologicheskij ocherk), Hozyajstvo kazahov na rubezhe XIX-XX vekov, Alma-Ata. (Kadyrbaev, MK 1980, Cattle breeding (historical and archeological essay), Kazakh economy at the turn of the XIX-XX centuries, Alma-Ata). (in Rus).

Karlsen 1978 - Karlsen, GG 1978, Trening i ispytanie rysakov, Moskva, 255 s. (Karlsen, GG 1978, Training and testing trotters, Moscow, $255 \mathrm{p}$ ). (in Rus).

Kiryushin, Tishkin 1997 - Kiryushin, YuF, Tishkin, AA 1997, Skifskaya ehpoha Gornogo Altaya, Ch.1, Barnaul, 232 s. (Kiryushin, YuF, Tishkin, AA 1997, Scythian epoch of Mountainous Altai, Part 1, Barnaul, 232 p). (in Rus).

Kiselev 1951 - Kiselev, SV 1951, Drevnyaya istoriya YUzhnoj Sibiri, Moskva, 645 s. (Kiselev, SV 1951, The Ancient History of Southern Siberia, Moscow, 645 p). (in Rus).

Kovalevskaya 1977 - Kovalevskaya, VB 1977, Kon'i vsadnik, Moskva, 152 s. (Kovalevskaya, VB 1977, Kon' i vsadnik, Moscow, 152 p). (in Rus). 
Kuklina 1985 - Kuklina, IV 1985, EHtnogeografiya Skifii po antichnym istochnikam, Leningrad, 206 s. (Kuklina, IV 1985, Scythian ethnography on ancient sources, Leningrad, 206 p). (in Rus).

Majdar 1981 - Majdar, M 1981, Pamyatniki istorii i kul'tury Mongolii, Moskva, 74 s. (Majdar, M 1981, Monuments of history and culture of Mongolia, Moscow, 74 p). (in Rus).

Margulan, Akishev, Kadyrbaev 1966 - Margulan, AH, Akishev, KA, Kadyrbaev, MK, Orazbaev, AM 1966, Drevnyaya kul'tura Central'nogo Kazahstana, Alma-Ata, 455 s. (Margulan, AH, Akishev, KA, Kadyrbaev, MK, Orazbaev, AM 1966, Ancient culture of Central Kazakhstan, Alma-Ata, 455 p). (Rus).

Marsadolov 1985 - Marsadolov, LS 1985, Hronologiya kurganov Altaya (VIII-IV vv. do n.eh.): Avtoref. dis.: kand. ist., Nauka, Leningard, 16 s. (Marsadolov, LS 1985, Chronology of Altai mounds (VIIIIV centuries BC): Abstract of the dissertation. disc .: cand. hist., Nauka, Leningard, $16 \mathrm{p})$. (in Rus).

Piotrovskij 1949 - Piotrovskij, BB 1949, Skify v Zakavkaz'e, Uchenye zapiski LGU, Vyp.15 (85), S.172189. (Piotrovskij, BB 1949, Scythians in Transcaucasia, Scientists' Notes of Leningrad State University, issue 15(85), P.172-189). (in Rus).

Rudenko 1953 - Rudenko, SI 1953, Kul'tura naseleniya Gornogo Altaya v skifskoe vremya, MoskvaLeningrad, 402 s. (Rudenko, SI 1953, Culture of the population of the Altai Mountains in the Scythian period, Moscow-Leningrad, $402 \mathrm{p}$ ). (in Rus).

Rudenko 1961 - Rudenko, SI 1961, K voprosu o formah sktovodcheskogo hozyajstva i o kochevnikah, Materialy po ehtnografii. Vypusk 1. Geograficheskoe obshchestvo Soyuza SSR, Leningrad, S.2-15. (Rudenko, SI 1961, On the question of the forms of the nomadic economy and the nomads, Materials on ethnography. Issue 1. Geographical Society of the USSR, Leningrad, P.2-15). (in Rus).

Rudenko 1960 - Rudenko, SI 1960, Kul'tura naseleniya Central'nogo Altaya v skifskoe vremya, Moskva - Leningrad, 359 s. (Rudenko, SI 1960, Culture of the population of Central Altai in Scythian time, Moscow-Leningrad, 359 p). (in Rus).

Samashev 2011 - Samashev, Z 2011, Berel, Almaty, 236 s. (Samashev, Z 2011, Berel, Almaty, 236 p). (in Rus).

Schmidt 1957 - Schmidt, E 1957, Persepolis: V.1-2, Chicago, 297 s. (Schmidt, E 1957, Persepolis: I.12, Chicago, 297 p). (in Rus).

SHer 1980 - Sher, YAA 1980, Petroglify Srednej i Central'noj Azii, Moskva, 328 s. (Sher, YaA 1980, Petroglyphs of Central and Central Asia, Moscow, 328 p). (in Rus).

SHul'ga 2008 - SHul'ga, PI 2008, Snaryazhenie verhovoj loshadi i voinskie poyasa na Altae, CH. I: Ranneskifskoe vremya, Red. Yu.F.Kiryushin, A.A.Tishkin, Azbuka, Barnaul, 276 s. (SHul'ga, PI 2008, Equestrian equipment and military belts in the Altai, Ch. I.: Early Scythian time, Editor. Yu.F. Kiryushin, A.A. Tishkin, Azbuka, Barnaul, 276 p). (in Rus).

Smirnov 1964 - Smirnov, KF 1964, Savromaty, Moskva, 579 s. (Smirnov, KF 1964, Sauromates, Moscow, 579 p). (in Rus).

Sorokin 1966 - Sorokin, SS 1966, Pamyatniki rannih kochevnikov v verhov'yah Buhtarm, Arheologicheskij sbornik Gosudarstvennogo EHrmitazha, Vyp. 8. (Sorokin, SS 1966, Monuments of the early nomads in the upper reaches of Bukhtarma, the Archaeological Collection of the State Hermitage, Issue 8). (in Rus).

Sorokin 1974 - Sorokin, SS 1974, Cepochka kurganov vremeni rannih kochevnikov na pravom beregu KokSu (YUzhnyj Altaj), Arheologicheskij sbornik gosudarstvennogo ehrmitazha, Vyp.16, Leningrad, S.6291. (Sorokin, SS 1974, A chain of early mounds of nomads on the right bank of Kok-Su (Southern Altai), Archaeological collection of the State Hermitage, Issue 16, Leningrad, P.62-91). (in Rus).

Sorokin 1969 - Soroki, SS 1969, Novyj pamyatnik VII-VI vv. do n.eh. na YUzhnom Altae, Sovetskaya arheologiya, №2, S. 249-252. (Soroki, SS 1969, New monument of the VIII-VI centuries. BC. on the Southern Altai, Soviet archeology, № 2, P. 249-252). (in Rus).

Stepanova 1986 - Stepanova, NF 1986, Kuyumskij tip pamyatnikov VIII-VI vv. do n.eh, Skifskaya ehpoha Altaya: Tezisy dokladov k konferencii, Barnaul, S.79-81. (Stepanova, NF 1986, Kiyumsky type of monuments VIII-VI centuries. BC, Scythian epoch of Altai: Abstracts of papers for the conference, Barnaul, P.79-81). (in Rus).

Tallgren 1917 - Tallgren, AM 1917, Collestion Tovostine, Helsinki, 93 s. (Tallgren, AM 1917, Collestion Tovostine, Helsinki, 93 p). (in Rus).

Terenozhkin 1976 - Terenozhkin, Al 1976, Kimmerijcy, Kiev, 223 s. (Terenozhkin, Al 1976, Cimmerians, Kiev, 223 p). (in Rus).

Urusov 1911 - Urusov, SP 1911, Kniga o loshadi, T.1, 2, Sankt-Peterburg. (Urusov, SP 1911, The book is about a horse, T.1, 2, Saint-Petersburg). (in Rus).

Vitt 1952 - Vitt, V 1952, Loshadi Pazyrykskih kurganov, Sovetskaya arheologiya, №16, S.185-224. (Vitt, V 1952, The horses of Pazyryk burial mounds, Soviet archeology, №16, P.185-224). (in Rus).

Vishnevskaya 1975 - Vishnevskaya, OA 1975, Culture of the Saka tribes of the lower reaches of the Syr Darya in the UE-U1 centuries. BC, Moscow, 160 p. (Vishnevskaya, OA 1975, Culture of the Saka tribes of the lower reaches of the Syr Darya in the UE-U1 centuries. BC, Moscow, 160 p). (in Eng). 